\title{
Evaluation of Various Nitrogen Indices in N-Fertilizers with Inhibitors in Field Crops: A Review
}

\author{
Antigolena Folina ${ }^{1}$, Alexandros Tataridas ${ }^{1}{ }^{\oplus}$, Antonios Mavroeidis ${ }^{1}$, Angeliki Kousta ${ }^{1}\left(\right.$, Nikolaos Katsenios ${ }^{2}{ }^{\circledR}$, \\ Aspasia Efthimiadou 2(1), Ilias S. Travlos ${ }^{1}{ }^{(\mathbb{D}}$, Ioannis Roussis $\left.{ }^{1}{ }^{(}\right)$, Mohammed K. Darawsheh ${ }^{3}$, \\ Panagiota Papastylianou ${ }^{1}$ and Ioanna Kakabouki ${ }^{1, *(1)}$ \\ 1 Laboratory of Agronomy, Department of Crop Science, Agricultural University of Athens, \\ 11855 Athens, Greece; folinanti@gmail.com (A.F.); a.tataridas@gmail.com (A.T.); \\ antoniosmauroeidis@gmail.com (A.M.); aggelikh.kousta@gmail.com (A.K.); travlos@aua.gr (I.S.T.); \\ iroussis01@gmail.com (I.R.); ppapastyl@aua.gr (P.P.) \\ 2 Institute of Soil and Water Resources, Department of Soil Science of Athens, Hellenic Agricultural \\ Organization DEMETER, Sofokli Venizelou 1, 14123 Lykovrissi, Greece; nkatsenios@gmail.com (N.K.); \\ sissyefthimiadou@gmail.com (A.E.) \\ 3 Institute of Industrial \& Forage Crops, Hellenic Agricultural Organization DEMETER, National Cotton \\ Classification Centre, 1st km Karditsa-Mitropili, 43100 Karditsa, Greece; m.daraouse@gmail.com \\ * Correspondence: i.kakabouki@gmail.com
}

\section{check for} updates

Citation: Folina, A.; Tataridas, A.; Mavroeidis, A.; Kousta, A.; Katsenios, N.; Efthimiadou, A.; Travlos, I.S.; Roussis, I.; Darawsheh, M.K.;

Papastylianou, P.; et al. Evaluation of Various Nitrogen Indices in $\mathrm{N}$-Fertilizers with Inhibitors in Field Crops: A Review. Agronomy 2021, 11, 418. https://doi.org/10.3390/ agronomy11030418

Academic Editor: Petronia Carillo

Received: 12 January 2021

Accepted: 22 February 2021

Published: 25 February 2021

Publisher's Note: MDPI stays neutral with regard to jurisdictional claims in published maps and institutional affiliations.

Copyright: (c) 2021 by the authors. Licensee MDPI, Basel, Switzerland. This article is an open access article distributed under the terms and conditions of the Creative Commons Attribution (CC BY) license (https:/ / creativecommons.org/licenses/by/ $4.0 /)$.

\begin{abstract}
Nitrogen (N) management remains a global challenge for the sustainability of diversified farming systems. Field crops are often over-supplied with nitrogen by farmers aiming to high productivity. Although the increase of nitrogen rates leads in many instances to high yields, degree of effectiveness for nitrogen use remains low. Urease and nitrification inhibitors are technologies which have been present in the fertilizers market at least 50 years. Inhibitors exploitation ensures long-term nitrogen release and improved $\mathrm{N}$-uptake by plants and $\mathrm{N}$-storage in seeds and silage. Avail of inhibitors, such as the decline of nitrogen leaching in form of $\mathrm{NO}_{3}{ }^{-}$, reduction of emissions in $\mathrm{NH}_{3}$ form, and rise of yield, are some of the desirable attributes that are derived from their integration in fertilization schedules. This review reports the evaluation of applied nitrogen, with inhibitors, and field crops based on nitrogen indices. The examined $\mathrm{N}$-indicators include Nitrogen use efficiency (NUE), Nitrogen Utilization Efficiency (NUtE,) Nitrogen Agronomic Efficiency (NAE), Nitrogen Harvest Index (NHI), and N uptake. This review gathered all, to the best of our knowledge, available data regarding the utilization of nitrification and urease inhibitors under an exclusively agronomic perspective. Either dual or single use of nitrification and urease inhibitors has been reported to significantly increase yield components and promote nitrogen uptake. To conclude, the assessment of N-related indices is vital to promoting sustainability in diversified farming systems, while the integration of inhibitors in national $\mathrm{N}$ fertilizations schemes may contribute to system profitability through enhancement of N-supply to crops.
\end{abstract}

Keywords: nitrogen indices; urease inhibitors; nitrification inhibitors; NUE; NHI; NAE; NUtE; field crops

\section{Introduction}

\subsection{The Need for Slow-Release Fertilizers}

While the world population has almost doubled in last 50 years, and meat consumption has been skyrocketing, an increase in agricultural production is required to match projected demand; therefore, agriculture aims to rise crop performance [1-3]. As a result, over the past decade, intensification of crops has been achieved through excessive amounts of nitrogen application [4]. For the time being, many researchers have observed that more than half of the applied $\mathrm{N}$ fertilizer in crops is currently lost to the environment [5-7]. In particular, Lassaletta et al. demonstrated that only $47 \%$ of globally applied nitrogen is transformed into harvest products, in contrast to $68 \%$ in the $1960 \mathrm{~s}[6,8]$. 
Inefficient $\mathrm{N}$ use in agriculture has created several environmental problems and concerns [9]. The over application of inorganic fertilizers to the soil, along with nitrogen leaching is responsible for the contamination of groundwater [10]. Another problem that has arisen due to the excessive use of inorganic fertilizers is eutrophication, a form of water pollution, caused mainly by nitrogen [11]. Moreover, regarding water quality issues related to agriculture, an inspection of $\mathrm{N}$ emission from different routes and sources in inland waters and water catchment areas are attended, in order to guarantee water quality $[12,13]$.

Since intensive agriculture has such an important impact on climate change and the environment, more environmentally friendly practices have been adopted in the last few years. Consequently, cultivation practices must be accomplished in a more precise way to increase crop performance; hybrid breeding is considered one of these practices [14]. Furthermore, the capacity for land, natural resource management, and conflict prevention need to be improved [15]. At the same time, although the fertilizer industry has changed considerably [16], nitrogen remains by far the main element used in synthetic fertilizers [17]. However, the need for improved nitrogen use efficiency in crops is imperative to design sustainable farming systems [5]. As a result, novel fertilizers with inhibitors and new technologies were introduced in the global market to reduce nitrogen leaching and enhance nitrogen utilization [18]. Slow-release fertilizers (SRF) are regularly related to nitrogenbased fertilizers [19]. Nitrogen management must be improved to minimize the undesired and detrimental environmental degradation, while achieving sustainable nourishment of the multiplying population. The overall efficiency of applied $\mathrm{N}$ differs widely among climatic zones and crops [20].

\subsection{Short History and Broad Classification of Slow-Release Fertilizers}

The aforementioned reasons led to a new trend in the fertilizer industry: slow- or controlled-release fertilizers (SRF or CRF). There is no endorsed dissimilarity between slow-release and controlled-release fertilizers [21]. These fertilizers are also known as controlled-availability fertilizers, delayed-release fertilizers, metered-release fertilizer, or slow-acting fertilizers [20]. SRF was firstly reported during the 1920s, although their market did not show growth until the 1960s [22]. The industry of these fertilizers is evolving considerably in the 21st century with an annual growth rate of $6.5 \%$ from 2014 to 2019 [22].

Classifications and definitions of SRFs vary depending on the legislation consulted. According to the European Committee for Standardization (CEN), there are three requirements for the characterization of fertilizer as SRF. Firstly, release of up to $15 \%$ of the fertilizer nutrients must occur within $24 \mathrm{~h}$ of application; secondly, $75 \%$ of them should be released in 28 days; and thirdly, at least about $75 \%$ release must be conducted at the stated release time. Slow controlled-release fertilizer (SRF) is defined as a new type of fertilizer with a lower carbon content than conventional [22]. Additionally, in the 57th Official Edition, the Association of American Plant Food Control Officials (AAPFCO) defined slow-release fertilizer as a fertilizer that depletes its nutrients later, after its application [23]. Yamamoto et al. noticed that the main feature of these fertilizers is the duration of nutrient release; SRFs have a longer nutrient release time than traditional ones; hence, nutrient uptake is prolonged by plants [24].

There are many differences between slow-release and conventional fertilizers. The main difference that directly concerns farmers and producers is the cost. SRFs are significantly more expensive than traditional fertilizers. Besides, their technology (with regard to its mode of operation) and application method are more familiar to farmers. However, the nutrient efficiency supply of SRF is higher compared to traditional. Last but not least, is the negative environmental impact which is remarkably higher with the use of traditional fertilizers [22]. However, the risk is that their release is not well stabilized and is influenced by some additional factors, such as microbial activity, $\mathrm{pH}$, organic matter, temperature, and moisture [25]. 
The gradual release of nutrients is accomplished by a variety of mechanisms. Some of these include controlled water solubility of the material by semi-permeable coatings, blockage, protein materials, or other chemical forms, by slow hydrolysis of low molecular weight water-soluble compounds, or by other unknown means [26,27].

According to the literature, there are many classifications of SRFs. Indeed, many researchers have mentioned that there is no united and standardized classification for this type of fertilizer [22,28]. In the literature, many categorizations vary over time [29]. The latest classification was reported by Fu et al. [22]. This classification of SRF is based on the principle of slow controlled release, and there are three classes: (1) physical type, including coated and matrix-based; (2) chemical type, including chemically bonded and chemically inhibited; and (3) compound type, including physical combination (coated with matrix method), physical-chemical combination, and chemical combination (chemical combination with inhibitor method).

\subsection{A Brief Overview of the Study}

The use of urease and nitrification inhibitors is an approach that is adopted to improve fertilizer performance in agriculture and lessen urea and nitrogen emission of pollutants. Nevertheless, in the field, slow-release technology fertilizers might not meet $\mathrm{N}$ crop demands and would not show an agronomic benefit over conventional $\mathrm{N}$ fertilizer applications [30]. The development of nitrification and urease inhibitors is a time-consuming and expensive process on account of their special traits [21]. One of these is the restriction of rainfall or irrigation conditions which deactivate the formulation for slow release for both inhibitors; nitrification and urease [31]. Additionally, a higher urea volatility was observed with late-fall and winter applications in cold and wet soils compared to spring applications in warmer soils [32].

In order to be evaluated, fertilization types and their effectiveness, optimum fertilization rate for each crop, reduction of $\mathrm{N}$ losses, and nitrogen indices are used [25]. There are many indicators so as to be estimated the uptake nitrogen from plants. In older literature, indices, such as N translocation efficiency (NTE) from vegetative plant parts to grain, dry matter translocation efficiency (DMTE), contribution of pre-anthesis assimilates to yield (CPAY), and Post-anthesis N uptake (PANU), are mentioned $[33,34]$. However, in recent research, nitrogen use efficiency (NUE) is consider as the most calculated [35]. Another important indicator is the nitrogen harvest index (NHI), which is informed regarding distribution of nitrogen in the plant and, more specifically, in which parts of the plant the most quantities accumulate [27].

The present study aimed to review the literature in order to evaluate the nitrogen indices in N-fertilizers with inhibitors in field crops of fertilizers with inhibitors with nitrogen indices. The inflow of slow release fertilizers has become the sword of modern agricultural development. The increase of utilization of this kind of fertilizer bears testament to the fact that it is universally accepted. However, a key goal of using this type of fertilizer is also to increase the exploitation of nitrogen unit fertilizers: on the one hand, to significantly reduce nitrogen $\left(\mathrm{NO}_{3}{ }^{-}\right)$leaching into the environment; on the other hand, to increase the profitability of fertilizer use for farmers. Firstly, this review intends to cite recent literature regarding the performance of urease and nitrification inhibitors as components of fertilization programs in plenty field crops through an agronomic perspective. The use of inhibitors, either urease or nitrification or both, is evaluated in major (wheat, maize, rice, cotton) and other field crops. It is crucial that, in the fertilizer industry, horticulture and turfgrass has been common for decades as their higher price is not considered as an issue in these sectors. The methodology was either the collection of nitrogen indices values or their calculation from the given values in each study. At that point, indices values under traditional fertilizers and fertilizers inhibitors were compared. Under this context, we did not deal with environmental or soil 'issues', such as emissions. Finally, nitrogen indices are connected with each crop orientation for the main field and novel crops. 


\section{Fertilizers Inhibitors and Their Importance in Agriculture}

\subsection{Urease Inhibitors (UI)}

Urea is considered as one of the most widely used nitrogen fertilizers worldwide owing to its high content of $\mathrm{N}(46 \%)$ and the relatively low cost per unit $\mathrm{N}$ [36]. Following urease in soil, urea undergoes hydrolysis via the urease enzyme or volatilization, increasing $\mathrm{pH}$ soil of surrounding area of the granules and resulting in $\mathrm{NH}_{3}$ losses up to $16 \%$ of $\mathrm{N}$ applied worldwide; $\mathrm{NH}_{3}$ losses could reach up to $40 \%$ or more under warm and humid conditions $[37,38]$.

Urease is a nickel-dependent enzyme that catalyzes the hydrolysis of urea to two moles of ammonia $\left(\mathrm{NH}_{3}\right)$ and one molar of carbon dioxide $\left(\mathrm{CO}_{2}\right)$. The first scenario is the hydrolysis of urea which provides $\mathrm{NH}_{3}$ which, in turn, is converted to ammonium $\left(\mathrm{NH}_{4}{ }^{+}\right)$ in the soil water so that plants can receive them; the second scenario is the volatilization of $\mathrm{N}$ as $\mathrm{NH}_{3}$ [37]. The action of urease inhibitors is, firstly, to slow down the conversion of urea to $\mathrm{NH}_{4}{ }^{+}$and, secondly, to decline volatilization of $\mathrm{NH}_{3}$. As a result, a significant percentage of the applied urea can be diffused into soil $[39,40]$. There are four different ways in which urease inhibitors can inhibit urease enzymes and delay urea hydrolysis [41].

A lot of compounds, physical and chemical, have been investigated for their potential to inhibit soil urease activity [42]. However, the most successful is widely the $\mathrm{N}$-(n-butyl) thiophosphorictriamide (NBPT). The NBPT market has been grown $16 \%$ per year for the last 10 years in virtue of significant low $\mathrm{NH}_{3}$ losses compared to urea [38]. Although effectiveness is affirmed, researchers are trying to enhance the period of inhibition and the shelf life of NBPT-treated urea [38]. Utilization of NBPT decreased $\mathrm{NH}_{3}$ loss up to $66 \%$ from urea [35].

There are three groups of synthetic compounds concerning their structure or ties mode with urease. The first one contains organic or inorganic compounds (e.g., alk(en)ylthiosulfinate, hydroquinone, p-benzoquinone) that can react with sulfhydryl (mercapto) groups of urease; the second is metal-chelating compounds (e.g., caprylohydroxamic acid, acetohydroxamic acid) that can form a complex with one of the $\mathrm{Ni}$ atoms at the active site of urease; and third are competitive inhibitors (e.g., hydroxyurea, phosphoramides, phenyl phosphorodiamidate (PPDA), N-(n-butyl) thiophosphorictriamide (nBTPT) that are similar to urea structure and can bind to the active site of urease but are not readily hydrolyzed by urease $[39,43]$. The most frequently used urease inhibitor were mentioned that is thiophosphoric-triamide (NBPT) [25,44].

\subsection{Nitrification Inhibitors (NI)}

Gaseous N emission in rice paddy fields were up to $10-60 \%$ of the N fertilizer applied [45]. The role of nitrification inhibitors is firstly to lessen the conversion of ammonium $\left(\mathrm{NH}_{4}{ }^{+}\right)$to nitrate $\left(\mathrm{NO}_{3}\right)$, which is considered as a significant pathway of nitrate leaching in agriculture [46]. Secondly, nitrous oxide $\left(\mathrm{N}_{2} \mathrm{O}\right)$ emissions, which are considered a greenhouse gas, are reduced into atmosphere. However, $\mathrm{N}_{2} \mathrm{O}$ emission is not a major factor for plant nutrition due to low nitrogen loss amounts $[47,48]$. Tens of commercial inhibitors have been patented, of which four inhibitors (Nitrapyrin, dicyandiamide (DCD), NBPT, and HQ) have application in agriculture. Nitrification inhibitors ordinally rise $\mathrm{NH}_{3}$ volatilization, and, if blended with urease inhibitors, reduction of $\mathrm{NH}_{3}$ loss would partially offset [38]. The addition of nitrification inhibitors to urease decreased by $38 \% \mathrm{NH}_{3}$ losses in the wheat field [49]. In the paddy field, ammonia and nitrous oxide were declined up to $90 \%$ by using controlled release urea [50].

Moreover, nitrification inhibitors could decline soil acidification; this decline helps to reduce $\mathrm{NH}_{3}$ loss by blocking nitrification [51]. The most used nitrification inhibitor is considered dicyandiamide (DCD) [52]. DCD has a solubility in water $23.0 \mathrm{~g} / \mathrm{L}$ (at $13^{\circ} \mathrm{C}$ ), low relative volatility, and its mode of application is blended with urea or other solid nitrogen fertilizers [46]. 3,4-Dimethylpyrazole phosphate (DMPP) is a new nitrification inhibitor with highly advantageous properties, such as lower ecotoxic, which is blended with urea or other solid nitrogen fertilizers [53]. 


\subsection{Combination of Nitrate and Urease Inhibitors (UI and NI)}

To raise the efficacy of nitrogen use, the combination of the two above inhibitors could be applied. In other words, the two inhibition mechanisms are likely to be combined. However, the results are divided. On the one hand, results were not observed auspicious for nitrogen leaching and crop yields. This is probably due to the combination of two inhibitors and the action of one inhibitor on the other; one inhibitor can disarm the other one so nitrogen losses are not reduced [51,54].

Although the direct effect of nitrification inhibitor on the urease inhibitor was not ratified, the concentration of $\mathrm{NH}_{3} / \mathrm{NH}_{4}{ }^{+}$remained high for a longer period, and volatilization losses were carried on [55]. On the other hand, the interaction of the two inhibitors is influenced by soil properties [52]. Presented in Figure 1 is the activity of urease and nitrification inhibitors. Blend of urease and nitrate inhibitors still decreased $\mathrm{NH}_{3}$ loss compared to pure urea; however, $\mathrm{NH}_{3}$ losses are less than using only urease inhibitor [51]. Regarding only crop yield, the application of both inhibitors has led to a significant increase compared to a single inhibitor $[25,56]$.

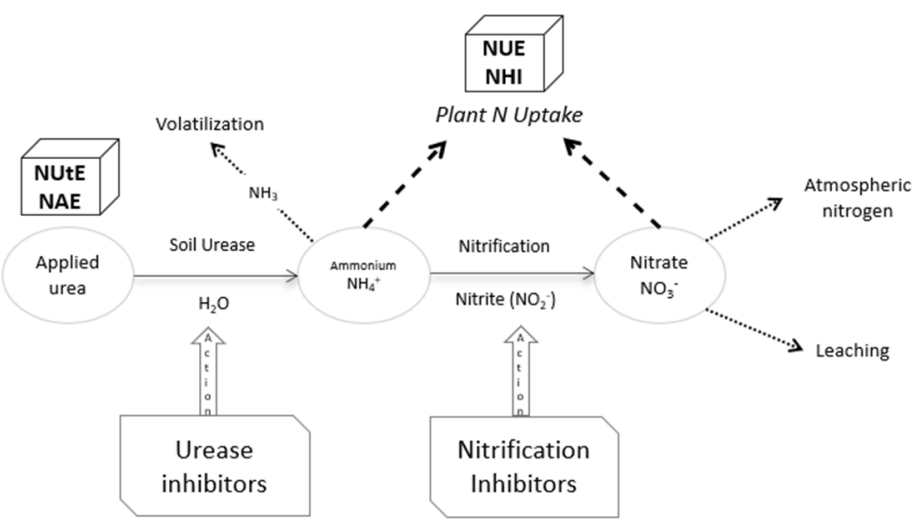

Figure 1. Urease inhibitors and nitrification inhibitors activity.

\section{Nitrogen Indices}

\subsection{Nitrogen Use Efficiency (NUE)}

Nitrogen efficiency is reduced by seasonal conditions, crop diseases, $\mathrm{N}$ losses from the soil as gases, leaching of $\mathrm{N}$, or immobilization of $\mathrm{N}$ in organic forms. The efficiency of the conversion of fertilizer into grains/seeds and shoots is considered as one of the major grower concerns. NUE index presents the yield in seed and biomass $(\mathrm{kg})$ per unit of applied $\mathrm{N}$ fertilizer $\mathrm{N}$. It is a net number [57]. The equation is as follows:

$$
\mathrm{NUE}=\frac{\mathrm{N} \text { uptake }_{\text {fert }}-\mathrm{N} \text { uptake }}{\text { control }}
$$

$\mathrm{N}$ uptake $_{\text {fert }}=$ total $\mathrm{N}$ (in shoots and seeds) under applied $\mathrm{N}$ fertilization, $\mathrm{N}$ uptake control $=$ total $\mathrm{N}$ (in shoots and seeds) without fertilizer.

This indicator can be differentiated depending on the production direction of the crop. In case the produced product is only seeds (and not biomass), then it concerns $\mathrm{N}$ uptake in seed or tubers in the case of potatoes. In NUE parameter, $\mathrm{N}$ could come not only from fertilizer $\mathrm{N}$ (applied $\mathrm{N}$ ) but also from soil mineral $\mathrm{N}$ ( $\mathrm{N}$ min). However, in this study, only applied $\mathrm{N}$ was considered.

\subsection{Nitrogen Utilization Efficiency (NUtE)}

This ratio indicates seed yield $\left(\mathrm{kg} \mathrm{ha}^{-1}\right)$ to $\mathrm{N}$ concentration $\left(\mathrm{kg} \mathrm{N}^{-1}\right)$ in the aboveground part of the crop [58]. The equation is:

$$
\mathrm{NUtE}=\frac{\text { Seed yield }}{\text { Above ground N }}
$$


To use the above index, it is necessary to calculate the entire nitrogen content of the whole above-ground part of the plant, including seeds.

\section{3. $N$ Yield and Protein Yield}

To evaluate crop yield in $\mathrm{N}$, the concentration in $\mathrm{N}(\%)$ was multiplied by the crop dry weight $\left(\mathrm{kg} \mathrm{ha}^{-1}\right)$.

$$
\mathrm{N} \text { yield }=\mathrm{N} \text { concentration }(\%) * \text { Yield biomass }\left(\mathrm{kg} \mathrm{ha}^{-1}\right)
$$

The protein yield was multiplied by yield $\mathrm{N}\left(\mathrm{kg} \mathrm{ha}^{-1}\right)$ on Jones' factor which is a nitrogen: protein conversion factor [59].

$$
\text { Protein yield }=\mathrm{N} \text { yield } * \text { Jones }^{\prime} \text { s factor }
$$

\subsection{Aboveground N Uptake}

$\mathrm{N}$ uptake by the upper plant tissues and the reproductive organs is described by Equation (5) and can be used in multiple crops.

$$
\mathrm{N} \text { uptake }=\mathrm{N} \text { yield upper parts }\left(\mathrm{kg} \mathrm{N} \mathrm{ha}^{-1}\right)+\mathrm{N} \text { seed yield }\left(\mathrm{kg} \mathrm{N} \mathrm{ha}^{-1}\right)
$$

The upper part of the plant includes stems and leaves.

\subsection{Nitrogen Harvest Index (NHI)}

NHI was introduced by Ye et al. [60], and the formula is:

$$
\mathrm{NHI}=\frac{\mathrm{N} \text { seed }}{\mathrm{N} \text { uptake }}
$$

$\mathrm{N}$ seed $=$ nitrogen content in seeds,

$\mathrm{N}$ uptake $=$ nitrogen content in whole plant.

\subsection{Nitrogen Agronomic Efficiency (NAE)}

NAE index was given by Craswell and Godwin with the below equation [61]:

$$
\mathrm{NAE}=\frac{\text { Grain yield }_{\text {fertilized }}(\mathrm{kg})-\text { Grain yield }_{\text {unfertilized }}}{\text { Applied } \mathrm{N}(\mathrm{kg})} \frac{\mathrm{kg} \text { seed }}{\mathrm{kg} \mathrm{N} \text { fertilizer }}
$$

\section{Factors Affecting Nitrogen Indices}

A widely used indicator is the nitrogen use efficiency (NUE) which illustrates how to enhance nitrogen exploitation, namely how much nitrogen is applied to the crop and how much is used by plants [61]. The most efficient way to lessen $\mathrm{N}$ losses and cost is the enhancement of NUE [62]. The degree of effectiveness of $\mathrm{N}$ fertilizers declined with the increase of $\mathrm{N}$ fertilizer inputs; this increased application has harmful effects [63]. Moreover, many factors affect NUE, such as flooding, soil compaction, low SOM content, and, especially, drought reduced NUE [64]. Furthermore, breeding is aimed to enhance crop yields through NUE [65]. Legumes have a high NUE due to their ability to fix atmospheric $\mathrm{N}$ in the aboveground part of plants (their shoots and grains compared to grasses) [66]. In maize crops, higher NUE was observed in the cold-dry season compared to the hot-wet season [67]. Furthermore, nitrogen uptake and NUE were increased with the reduction of irrigation level up to $25 \%$ in maize, for both hot and cold seasons [67]. However, the effect depends on the irrigation rate and the weather. In soya crop, NUE could be enhanced with the genetic upgrade, and higher yield and higher quality products will be accomplished [68]. Attia et al. (2015) mention that intercropping of soya-corn positively affected NUE [69]. According to Kakabouki et al., NUE index was increased, while the fertilizer nitrogen rate was decreased; in soybean, cultivation NUE was 0.26 under 
$80 \mathrm{~kg} \mathrm{~N} \mathrm{ha}^{-1}$, and 0.17 under $120 \mathrm{~kg} \mathrm{~N} \mathrm{ha}^{-1}$ [52]. In wheat crop, NUE has risen in conventional tillage compared no-tillage [70]. NUE varied from 19.2 to 22.7 (kg of grain produced per $\mathrm{kg}$ of $\mathrm{N}$ supply) in comparison with conventional tillage [71].

Regarding NUE, there is a turning point of fertilized nitrogen above which NUE is begun to decrease or yield response slows down. In maize, it was noted that this amount of nitrogen is $150 \mathrm{~kg} \mathrm{~N} \mathrm{ha}^{-1}$, and, for winter wheat, it is approximately $50 \mathrm{~kg} \mathrm{~N}^{-1}$ [72]. It is considered as general rule for many crops, especially in the case of wheat (Triticum aestivum L.), that NUE was higher with low $\mathrm{N}$ rate $\left(42.7 \mathrm{~kg} \mathrm{DM} \mathrm{kg}^{-1} \mathrm{~N}\right)$ than at high $\mathrm{N}$ rate $\left(32.9 \mathrm{~kg} \mathrm{DM} \mathrm{kg}^{-1} \mathrm{~N}\right)$ [73]. NUE, in many crops, has risen in recent decades, which reduce $\mathrm{N}$ loss from agricultural production.

In the case of a growth period with low internal nutrient concentration, NUtE could provide information about the relationship between plant carbon and nutrient economies [74]. In wheat crops, $\mathrm{N}$ utilization efficiency was raised with a decreased fertilizer rate of $210 \mathrm{~kg} \mathrm{hm}^{-2}$ and a $50 \%$ ratio of $\mathrm{N}$ as topdressing [63]. The application of no-tillage instead of conventional tillage led to an increase in NUtE only in sequel wheat-faba bean, and wheat-berseem and not wheat-wheat [71]. NutE was higher at low rate nitrogen $\left(55.6 \mathrm{~kg} \mathrm{DM} \mathrm{kg}^{-1} \mathrm{~N}\right)$ than at high rate nitrogen $\left(41.9 \mathrm{~kg} \mathrm{DM} \mathrm{kg}^{-1} \mathrm{~N}\right)$ in bread wheat (Triticum aestivum L.) [73]. A comparison between perennial and annual grassland revealed higher NUtE in perennials owing to the rise of nitrogen concentration in perennial plant parts [74].

$\mathrm{N}$ uptake or $\mathrm{N}$ yield was observed highly dependent on nitrogen rate in soya, even though soya belongs in legume family [52]. Similar results are noticed for flaxseed crops; while nitrogen rate was increased, $\mathrm{N}$ total in plants was significantly risen [56]. Plant $\mathrm{N}$ uptake was improved with a reduced fertilizer rate in wheat crops [63]. Szumigalski and Van Acker (2006) observed that $\mathrm{N}$ yield was significantly affected by crop [75]. Another factor that in effect here is the presence of crop herbicide; $\mathrm{N}$ yield was noticed higher after application of crop herbicide [75]. Additionally, $\mathrm{N}$ uptake was higher under conventional tillage compared to no-tillage. In bread, wheat grain protein content was found to be significantly influenced by $\mathrm{N}$ application rate timing of $\mathrm{N}$ application, and the highest rate gave the highest concentration of protein [76].

Another significant index is the nitrogen harvest index (NHI), which is a ratio between $\mathrm{N}$ accumulated in grain to $\mathrm{N}$ accumulated in whole plant. In soybean cultivation, $\mathrm{NHI}$ did not statistically differ for three nitrogen rates $\left(80,100\right.$, and $\left.120 \mathrm{~kg} \mathrm{~N} \mathrm{ha}^{-1}\right)$ and tillage; the more fertilized nitrogen, the lower NHI in soybean crop; namely, the lowest NHI value was under $120 \mathrm{~kg} \mathrm{~N} \mathrm{ha}^{-1}$. However, NHI was noticed around 0.8 for all operations due to the orientation of production were the seeds [52]. In flaxseed crop, NHI was ranged from 37.9 (without fertilizer) to $58.3\left(60 \mathrm{~kg} \mathrm{~N} \mathrm{ha}^{-1}\right)$ [56]. NHI ranged from 71 to $78 \%$ [70]. Lower $\mathrm{NHI}$ was observed after a wheat crop sequence for years than crop rotation [70].

In soybean crop, NAE was affected by fertilization nitrogen rate. It was increased under an elevated nitrogen rate [52]. NAE was raised by rotation in wheat crops [70].

\section{Impact of N Inhibitors on Fertilizer N Indices of Field Crops}

The addition of inhibitors has been reported to regulate the allocation of nitrogen in individual plant parts and lead to an increase of stored nitrogen in fruits, such as tomato cultivation [77]. Moreover, $\mathrm{N}$ losses to the environment due to leaching and emissions, in this way increasing the nitrogen use efficiency, are moderated with the use of inhibitors [78-81]. However, this attribute should be combined with proper nitrogen rates in order to be ensured efficient yield and reduced emissions simultaneously [82]. Utilization of (N-(nbutyl) thiophosphorictriamide (NPBT) result in increased yield from 0.8 to $10.2 \%$ in various crop species [38]. Concerning the operating costs of the enhanced efficiency nitrogen fertilizers, application rates are crucial for sufficient yield and exploitation of environmental benefits $[83,84]$. 
A lot of inhibitors have been incorporated worldwide in many fertilization plans in many crops. Except from synthetic inhibitors, lower-cost materials, such as calcium chloride, sodium thiosulphate, and other natural NI, have been suggested for further evaluation in field-scale $[85,86]$. Nitrification and urease inhibitors performance is significantly affected by timing (relevant crop growth stage), type (single or split), and rate of application $[42,87-90]$. Soil $\mathrm{pH}$ is also a key factor that guides the effectiveness of various inhibitors; while soil $\mathrm{pH}$ rises, slow release fertilizers activity is benefited and action of the inhibitors is not repressed [91]. It is imperative to be paid attention in increased rates of applied nitrogen since risk for $\mathrm{N}$ losses to the environment simultaneously raises [92,93]. However, some researcher observed that nitrogen use efficiency after the introduction of inhibitors is not always improved in complex cropping systems in terms of yield [81,94]. Therefore, it is imperative that use of inhibitors should be defined in today's agriculture $[18,95]$.

\subsection{Wheat}

The utilization of nitrification and urease inhibitors could be causally linked to the reduction of required $\mathrm{N}$ input in various crops. One of the first experiments reveals that application of pure nitrate yielded in lower accumulation of $\mathrm{N}$ in contrast to mix of ammonium and nitrate with DCD supplies; pure ammonium could have a toxic effect on plants, and nitrate nutrition may be relatively more energy-consuming [96]. Many strategies are aimed at reducing yield-scaled $\mathrm{N}$ oxides and enhancing bread quality in rainy Mediterranean areas [83]. The dual-use of inhibitors has been reported to significantly increase wheat yield and promote $\mathrm{N}$ uptake at harvest [97]. Yield components and NUE were increased and profitability remains high [97]. In cases of drought conditions, split-application of urea with both nitrification and urease inhibitors is proposed to provide sufficient yield, high-quality characteristics, and balanced nitrogen management [98]. The addition of a nitrification inhibitor (3,4 dimethylpyrazole succinic acid-DMPSA) and urease inhibitor (N-(n-butyl) thiophosphorictriamide-NBPT) serves a binary purpose; the reduction of $\mathrm{NH}_{3}$ and $\mathrm{N}_{2} \mathrm{O}$ emissions [99]. Agronomic and quality attributes of wheat exhibited significant positive results by using the urease inhibitor N-(2-Nitrophenyl) phosphoric triamide (2-NPT) in split-applied urea at $180 \mathrm{~kg} \mathrm{~N} \mathrm{ha}^{-1}$ [100]. The nitrification inhibitor DMPP in ammonium sulfate was able to aid late growing wheat genotypes by delaying the nitrification process for more than 6 weeks (Table 1) [101]. Nitrogen use efficiency could be further enhanced in cases of seed inoculation with microbes. This is a technique that proved quite efficient in wheat crop when it is combined with coated urea and urease inhibitor NBPT (Table 2) [102]. The same authors suggested that $140 \mathrm{~kg} \mathrm{~N} \mathrm{ha}^{-1}$ in urea form, along with seed inoculation, leads to higher wheat grain yield and satisfying nitrogen use efficiency (Table 2) [103]. However, nitrification inhibitors are limited in calcareous soils $(\mathrm{pH}>7)$ [97]. Higher NUE and wheat yield have not been previously reported (Table 3) [97]. DMPP applied in urea did not improve yield components and nitrogen use efficiency of durum wheat in Italy [104]. Moreover, the increase in NUE in wheat at a range of $9 \%$ after the introduction of nitrification and urease inhibitors is not necessarily linked with an increase in grain yield (Tale 3) [105]. In an analysis of various nitrogen management practices, the split application of urease inhibitors as topdressing at shooting stage of wheat managed to increase NUE value (>0.6), boost wheat grain yield, reduce $\mathrm{N}$ losses, and moderate net returns to farmers [88]. If wheat market price is relatively high, use of nitrification and urease inhibitors will increase net returns, providing US $\$ 107 \mathrm{ha}^{-1}$ at wheat price $\$ 220 \mathrm{Mg}^{-1}$ when enhanced urea is applied at $70 \mathrm{~kg} \mathrm{~N} \mathrm{ha}^{-1}$ at planting [106]. On the same wheat price, net profit cut to half when nitrogen fertilization was split-applied. Profitability rate in spring wheat under fertilization with the nitrification inhibitor nitrapyrin fluctuated between $25-33 \%$ across years, whereas the urease inhibitor NBPT in urea led to a rate of $50-52 \%$, separately (Table 3) [97]. 


\subsection{Maize}

In general, nitrification inhibitors could become an important component of crop rotation systems in order to increase yields and enhance agronomic efficiency [107]. Fertilizers with nitrification inhibitor increased NUE in the following year after application compared to a conventional fertilizer [108]. However, the mixture of inhibitors does not always ensure high yields [109] and occasionally performs even worse than conventional fertilizer in maize plants (Tables 1 and 2) [110]. The more complicated, the less effective were noticed for inoculated fertilizers [81]. Slow-release $\mathrm{N}$ fertilizer, with the method of organic coating, did not improve N uptake, NUE, or maize yield compared to conventional urea, $46 \% \mathrm{~N}$ (Table 3) [111]. On the contrary, a comparison of urea and polyolefin coated urea revealed that although total $\mathrm{N}_{2} \mathrm{O}$ emission value of the coated technology was almost one out of three of pure urea, similar patterns were observed on a cornfield [112]. Another study in maize was mentioned that urease inhibitor was used in urea at a rate of $96 \mathrm{~kg} \mathrm{~N} \mathrm{ha}^{-1}$ (Table 2) [113]. Coating with NBPT in urea led to a significant increase in maize yield and NUE compared to conventional $\mathrm{N}$ application rate at $120 \mathrm{~kg} \mathrm{~N} \mathrm{ha}^{-1}$. Researchers highlighted that application of NBPT coated urea increased efficiently the total $\mathrm{N}$ uptake and reduced the required $\mathrm{N}$ application with a view to higher yield. At the tassel fully emerged stage of maize, $21 \%$ higher NUE were approximately noticed under urea with NBPT than non-treated urea in a pot experiment [114]. Furthermore, significant reduced ammonia losses were observed [114]. In pre-plant applications of urea with NBPT urease inhibitor at $150 \mathrm{~kg} \mathrm{~N} \mathrm{ha}^{-1}$, applied either broadcast or broadcast and incorporated, showed 1.87-fold greater corn grain yield than control and 1.96-fold higher corn grain $\mathrm{N}$ uptake relative to control (Table 2) [115]. Urea with NBPT at a rate of $180 \mathrm{~kg} \mathrm{~N} \mathrm{ha}^{-1}$ showed greater agronomic efficiency than conventional urea, whereas, at the rate of $120 \mathrm{~kg} \mathrm{~N} \mathrm{ha}^{-1}$, there was no significant difference [116]. in similar cases as wheat, seed inoculation with microbes led to an increase in NUE and yield [103]. Nevertheless, serious economical limitations arise from the exploitation of synthetic inhibitors and more intensive nitrogen sources. According to Galindo et al. (2019), the highest profitability in maize cultivation (approximately per $60 \mathrm{~kg}$ sack US \$360) occurred under fertilization with urea at $100 \mathrm{~kg} \mathrm{~N} \mathrm{ha}^{-1}$ and with the addition of Azospirillumbrasilense (Table 2) [103]. The profit decreased under the use of NBPT in urea (approximately US $\$ 160$ at $100 \mathrm{~kg} \mathrm{~N} \mathrm{ha}^{-1}$ ) and almost eliminated in the absence of the bacterium (approximately US $\$ 6$ at $100 \mathrm{~kg} \mathrm{~N} \mathrm{ha}^{-1}$ ). Although, use of double inhibitors (nitrification and urease) may increase costs, revenue from corn yield will balance the profit. Broadcast applied urea with dual inhibitors led to US $\$ 619 \mathrm{ha}^{-1}$ return in maize cultivation, derived from a three-year study, an amount $5.6 \%$ greater than the application with polymer-coated urea and $10.7 \%$ lower than anhydrous ammonia (Table 3) [117]. A meta-analysis in maize revealed that the nitrification inhibitor DCD provided approximately $\$ 110 \mathrm{ha}^{-1}$, a value significantly higher than using the NI DMPP [118].

\subsection{Rice}

The nitrification inhibitor nitrapyrin (2-chloro-6-(trichloromethyl)-pyridine, CP) significantly increased yield and NUE of rice in paddy soil under a 5-year study in China [119]. Moreover, another study on rice revealed that the urease inhibitor NBPT slightly increased yield compared to the typical urea application at $270 \mathrm{~kg} \mathrm{~N} \mathrm{ha}^{-1}$. However, total $\mathrm{N}$ uptake was approximately $10 \%$ higher than the fertilized control [120]. High soil temperature might act as a limiting factor for the performance of 2-chloro-6-(trichloromethyl)-pyridine in rice cultivation (Table 1) [121]. Application of nitrification inhibitors should be sitespecific, depending on several soil properties due to the strong linkage of the inhibitors with the bacteria communities [122]. More complicated mixes, such as a nitrification inhibitor (DCD), along with urease inhibitor (hydroquinone) at $300 \mathrm{~kg} \mathrm{~N} \mathrm{ha}^{-1}$ and biochar, might improve rice yield, NUE, and profitability (Table 3) [123]. Though the comparison of mode of action (i.e., urease inhibitors, nitrification inhibitors, or slow-release) did not differentiate the enhanced efficiency nitrogen fertilizers, yet the individual analysis of each 
product still revealed that NBPT [N-(n-butyl) phosphoric triamide] and neem coated were proved effective in the rise of rice yield, in contrast to PPDA and DCD, which were not effective [88]. In rice, the technology of coatings is also considered as an effectual way to improve $\mathrm{NUE}=$, yield, and decrease $\mathrm{N}$ loss through denitrification, ammonia volatilization $(\mathrm{AV})$, leaching, and surface runoff [124,125].

\subsection{Cotton}

In cotton crop, $\mathrm{N}$ yield was significantly increased by applying fertilizers with inhibitors; $\mathrm{N}$ yield was noticed $286.75 \mathrm{~kg} \mathrm{~N}^{-1}$ under urea with DCD + NBPT compared to $198.5 \mathrm{~kg} \mathrm{~N} \mathrm{ha}^{-1}$ which mentioned under urea (Table 3) [126]. There was an increase of $44.4 \%$ in $\mathrm{N}$ uptake or $\mathrm{N}$ yield with the use of urease and nitrification inhibitors. Furthermore, NUtE was significantly higher under urea with both inhibitors; NUtE was commemorated in 23.06 and 20.52 under pure urea. Nevertheless, the dual use of nitrification and urease inhibitors did not result in significant increases in cottonseed and lint yield with NAE remaining low across years [127]. With the application of urease inhibitors, fertilizers (in a split way) were observed to have a $4-12 \%$ yield rise for two cultivation years, whereas NUE was noticed similar to that between conventional and urease inhibitors [128]. Furthermore, conventional and urease inhibitors were identically yielded at rates of $140 \mathrm{~kg} \mathrm{ha}^{-1}$ and $210 \mathrm{~kg} \mathrm{ha}^{-1}$, respectively [128]. On the other hand, utilization of NBPT, DCD with urea, and polymer-coated urea did not affect yield, fiber quality, and $\mathrm{N}$ use under a drip-fertigated system in the arid region (Table 3) [82,129].

\subsection{Other Field Crops}

Nitrogen management proved to be enhanced in split-applied ammonium sulfate nitrate plus a nitrification inhibitor (3,4-dimethylpyrazole phosphate-DMPP) at $\frac{3}{4}$ of the typically recommended rate (urea at $160 \mathrm{~kg} \mathrm{~N} \mathrm{ha}^{-1}$ ) in potato cultivation in Brazil (Table 1) [90]. Furthermore, an application rate of $112 \mathrm{~N} \mathrm{~kg} \mathrm{ha}^{-1}$ of polyolefin coated urea was yielded equal with $269 \mathrm{~N} \mathrm{~kg} \mathrm{ha}^{-1}$ of traditional fertilizers. However, large size tubers were significantly lower with polyolefin coated urea compared to traditional fertilizer [112]. In potato crop, NUE ranged from 201 to 7.102, was calculated with tuber yield, and was declined with the increase of applied fertilizer; the more applied nitrogen, the higher values of NUtE due to a nonlinear relationship between nitrogen fertilizer and tuber potato yield [130]. This nonlinear relationship is presented at every crop. Regarding the total $\mathrm{N}$ uptake, values ranged from $97 \mathrm{~kg} \mathrm{~N} \mathrm{ha}^{-1}$ (control, without fertilizer) to $191 \mathrm{~kg} \mathrm{~N} \mathrm{ha}^{-1}$ $($ Urea + DCD + NBPT) in sweet potato crop. Additionally, NUE was significantly affected by inhibitors and was noticed high under urease and nitrification inhibitors. The highest NUE value was 0.492 in urea with double inhibitors treatment and the lowest was 0.016 in urea treatment. As regards NHI, in urea + DCD +NBPT treatment was observed the highest value (0.86). The lowest was noticed in control (0.62). With respect to NAE, the values ranged from 17.23 (Urea) to 47.047 (Urea + DCD +NBPT) (Tables 2 and 3) [25]. The nitrification inhibitor DCD did not enhance the stalk yield of sugarcane resulting in similar values when applied at $120 \mathrm{~kg} \mathrm{~N} \mathrm{ha}^{-1}$ [131]. Separately, the nitrification inhibitor CP in reduced rates of nitrogen (180 $\mathrm{kg} \mathrm{N} \mathrm{ha}^{-1}$ for tomato) applied as urea led to an increase in total yield and NUE, as it emerges from the study of Min et al. [77]. The addition of NI at reduced N application rates increased the total average yield approximately by $16 \%$ in comparison with the reduced $\mathrm{N}$ application rates. There was also a remarkable enhancement of NUE, since the addition of NI increased approximately by $84 \%$ the nitrogen use efficiency compared to reduced $\mathrm{N}$ applied rates. 
Grassland yield $11 \%$ more, NUE was observed 33\% higher, and $47 \%$ decrease in aggregated $\mathrm{N}$ loss (sum of $\mathrm{NO}_{3}{ }^{-}, \mathrm{NH}_{3}$, and $\mathrm{N}_{2} \mathrm{O}$, totaling $84 \mathrm{~kg} \mathrm{~N}$ ha $^{-1}$ ) with new types of fertilizers called enhanced-efficiency fertilizers [81]. Grassland productivity is proved to be enhanced with the utilization of urea fertilizers with the urease inhibitor NBPT [132]. The use of NI DCD and UI NBPT increased significantly camelina production in terms of grain yield, marking approximately $36 \%$ higher production than conventional urea [133]. The NI DMPP and the UI NBPT at a rate of $40 \mathrm{~kg} \mathrm{~N} \mathrm{ha}^{-1}$ were not able to increase biomass productivity and nitrogen agronomic efficiency of ryegrass (Lolium perenne) [134]. On the contrary, reduced rates of DMPP in urea resulted in higher yields and fewer $\mathrm{N}$ losses to the environment in pasture [135]. This pattern was not observed in grain sorghum (Sorghum bicolor), where DMPP fertilization rates should be increased to observe a significant enhancement in yield and nitrogen agronomic efficiency [136]. $\mathrm{N}_{2} \mathrm{O}$ emissions from urea were greatly reduced up to 81 and $35 \%$ using DCD and polyolefin-coated urea, respectively, in the barley field.

$\mathrm{N}$ fertilizer losses from polyolefin coated urea was noticed at only $1.9 \%$, in contrast to DCD $(10 \%)$. As a result, slow-release fertilizer with coated was indicated more profitable in irrigated barley crops [112]. Dry matter production and NUE were revealed lower under urea $\left[\mathrm{CO}\left(\mathrm{NH}_{2}\right)_{2}\right]$ than ammonium nitrate $\left(\mathrm{NH}_{4} \mathrm{NO}_{3}\right)$, urea ammonium nitrate (UAN), and ammonium thiosulfate $\left[\left(\mathrm{NH}_{4}\right)_{2} \mathrm{SO}_{4}\right]$ in bermudagrass just the first growing season, and not the second [137]. The use of the nitrification inhibitor DMPP (3,4-dimethylpyrazole phosphate) increased the marketable yield of cabbage by the first year [138], whereas slow-release $\mathrm{N}$ products (urea with sulfur or methylene urea) did not increase cabbage yield [31]. 
Table 1. Nitrification inhibitors use in different crops/regions/rates and their association with Nitrogen efficiency indices.

\begin{tabular}{|c|c|c|c|c|c|c|c|c|c|}
\hline \multirow{2}{*}{$\begin{array}{r}\text { Inhibitor } \\
\text { Nitrifica }\end{array}$} & \multirow{2}{*}{$\begin{array}{l}\text { N Application Rate } \\
\text { on inhibitors (NI) }\end{array}$} & \multirow[t]{2}{*}{ Crop(s) } & \multicolumn{2}{|c|}{$\begin{array}{l}\text { Yield (Approximate Upward and } \\
\text { Downward Trends Provoked by the } \\
\text { Utilization of Inhibitors) }\end{array}$} & \multirow{2}{*}{$\begin{array}{c}\text { NUE } \\
\text { Compared to } \\
\text { fertilized control } \\
\text { without inhibitors }\end{array}$} & \multirow[t]{2}{*}{ NUtE } & \multirow{2}{*}{\multicolumn{2}{|c|}{ 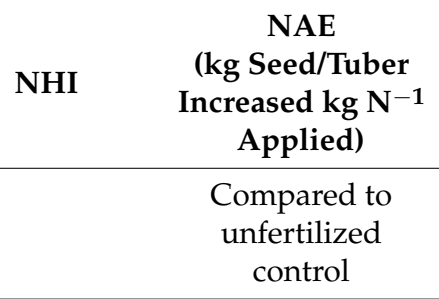 }} & \multirow[t]{2}{*}{$\begin{array}{c}\text { Country } \\
\text { References }\end{array}$} \\
\hline & & & $\begin{array}{l}\text { Compared to } \\
\text { unfertilized control }\end{array}$ & $\begin{array}{l}\text { Compared to } \\
\text { fertilized control } \\
\text { without inhibitors }\end{array}$ & & & & & \\
\hline $\mathrm{CP}$ & Urea: $180 \mathrm{~kg} \mathrm{~N} \mathrm{ha}{ }^{-1}$ & tomato & $\uparrow 120 \%$ & $\uparrow 21 \%$ & $\uparrow 55 \%$ & - & - & - & $\begin{array}{c}\text { China } \\
{[77]}\end{array}$ \\
\hline DMPP & $\begin{array}{l}\text { Ammonium } \\
\text { sulphate nitrate: } \\
160 \mathrm{~kg} \mathrm{~N} \mathrm{ha}^{-1} \\
\text { (split-applied) }\end{array}$ & potato & $\uparrow 104 \%$ & $\begin{array}{l}\uparrow 13.9 \% \text { (urea at } \\
160 \mathrm{~kg} \mathrm{~N} \mathrm{ha}^{-1} \text { ) }\end{array}$ & $\uparrow 50 \%$ & $\begin{array}{c}\text { 48-51 (at } \\
\text { maturation) }\end{array}$ & - & - & $\begin{array}{c}\text { Brazil } \\
{[90]}\end{array}$ \\
\hline DMPP & $\begin{array}{l}\text { Urea: } 180 \mathrm{~kg} \mathrm{~N} \mathrm{ha}^{-1} \\
\text { (single application) }\end{array}$ & maize & $\uparrow 34.4 \%$ & $\begin{array}{l}\uparrow 1.7 \%(\text { urea at } \\
225 \mathrm{~kg} \mathrm{~N} \mathrm{ha}^{-1} \text { ) }\end{array}$ & $\uparrow 4.8 \%$ (grain NUE) & - & 0.79 & 14.6 & $\begin{array}{c}\text { China } \\
{[110]}\end{array}$ \\
\hline DMPP & $\begin{array}{l}\text { Urea: } 300 \mathrm{~kg} \mathrm{~N} \mathrm{ha}^{-1} \\
\text { (split-applied 50:50) }\end{array}$ & maize & $\uparrow 70.4 \%$ & $\begin{array}{c}\uparrow 7 \% \text { (urea at } 300 \mathrm{~kg} \\
\mathrm{~N} \mathrm{ha}^{-1} \\
\text { split-applied) }\end{array}$ & $\begin{array}{c}\uparrow 4.3 \% \text { (three-year } \\
\text { average) }\end{array}$ & - & - & 12.7 & $\begin{array}{l}\text { China } \\
\text { [139] }\end{array}$ \\
\hline Nitrapyrin & $\begin{array}{l}\text { Urea: } 225 \mathrm{~kg} \mathrm{~N} \mathrm{ha}^{-1} \\
\quad \text { (split-applied) }\end{array}$ & cotton & $\uparrow 35 \%$ (lint yield) & $\begin{array}{c}\uparrow 4 \% \text { (lint yield; } \\
\text { urea at } 225 \mathrm{~kg} \mathrm{~N} \\
\text { ha }^{-1} \text { split-applied) }\end{array}$ & $\uparrow 5.7 \%$ & 7 & - & - & $\begin{array}{l}\text { China } \\
\text { [140] }\end{array}$ \\
\hline $\mathrm{DCD}$ & $\begin{array}{l}\text { Urea: } 160 \mathrm{~kg} \mathrm{~N} \mathrm{ha}^{-1} \\
\quad \text { (split-applied) }\end{array}$ & cotton & $\begin{array}{l}\uparrow 3.2 \text {-fold (lint yield) } \\
\uparrow 3 \text {-fold (seed cotton } \\
\text { yield) }\end{array}$ & $\begin{array}{l}\uparrow 13 \% \text { (lint yield) } \\
\uparrow 8.2 \% \text { (seed cotton } \\
\text { yield; urea at } \\
160 \mathrm{~kg} \mathrm{~N} \mathrm{ha}^{-1} \text { ) }\end{array}$ & - & $12-21$ & 0.72 & 20.6 (seed cotton) & $\begin{array}{c}\text { Greece } \\
\text { [126] }\end{array}$ \\
\hline $\mathrm{CP}$ & $\begin{array}{l}\text { Urea: } 180 \mathrm{~kg} \mathrm{~N} \mathrm{ha}^{-1} \\
\text { (single application) }\end{array}$ & $\begin{array}{c}\text { rice (early } \\
\text { and late) }\end{array}$ & $\begin{array}{l}\uparrow 129 \% \text { (five-year } \\
\text { average; early rice) } \\
\uparrow 56.7 \% \text { (five-year } \\
\text { average; late rice) }\end{array}$ & $\begin{array}{c}\uparrow 9.7 \% \text { (five-year } \\
\text { average; early rice; } \\
\text { split-applied urea at } \\
180 \mathrm{~kg} \mathrm{~N} \mathrm{ha}^{-1} \text { ) } \\
\uparrow 9.6 \% \text { (five-year } \\
\text { average; late rice; } \\
\text { split-applied urea at } \\
180 \mathrm{~kg} \mathrm{~N} \mathrm{ha}^{-1} \text { ) }\end{array}$ & $\begin{array}{c}\uparrow 10.3 \% \text { (early rice) } \\
\uparrow 8.8 \% \text { (late rice) }\end{array}$ & - & - & $\begin{array}{c}20.8 \text { (early rice) } \\
17.9 \text { (late rice) }\end{array}$ & $\begin{array}{l}\text { China } \\
\text { [121] }\end{array}$ \\
\hline
\end{tabular}


Table 1. Cont.

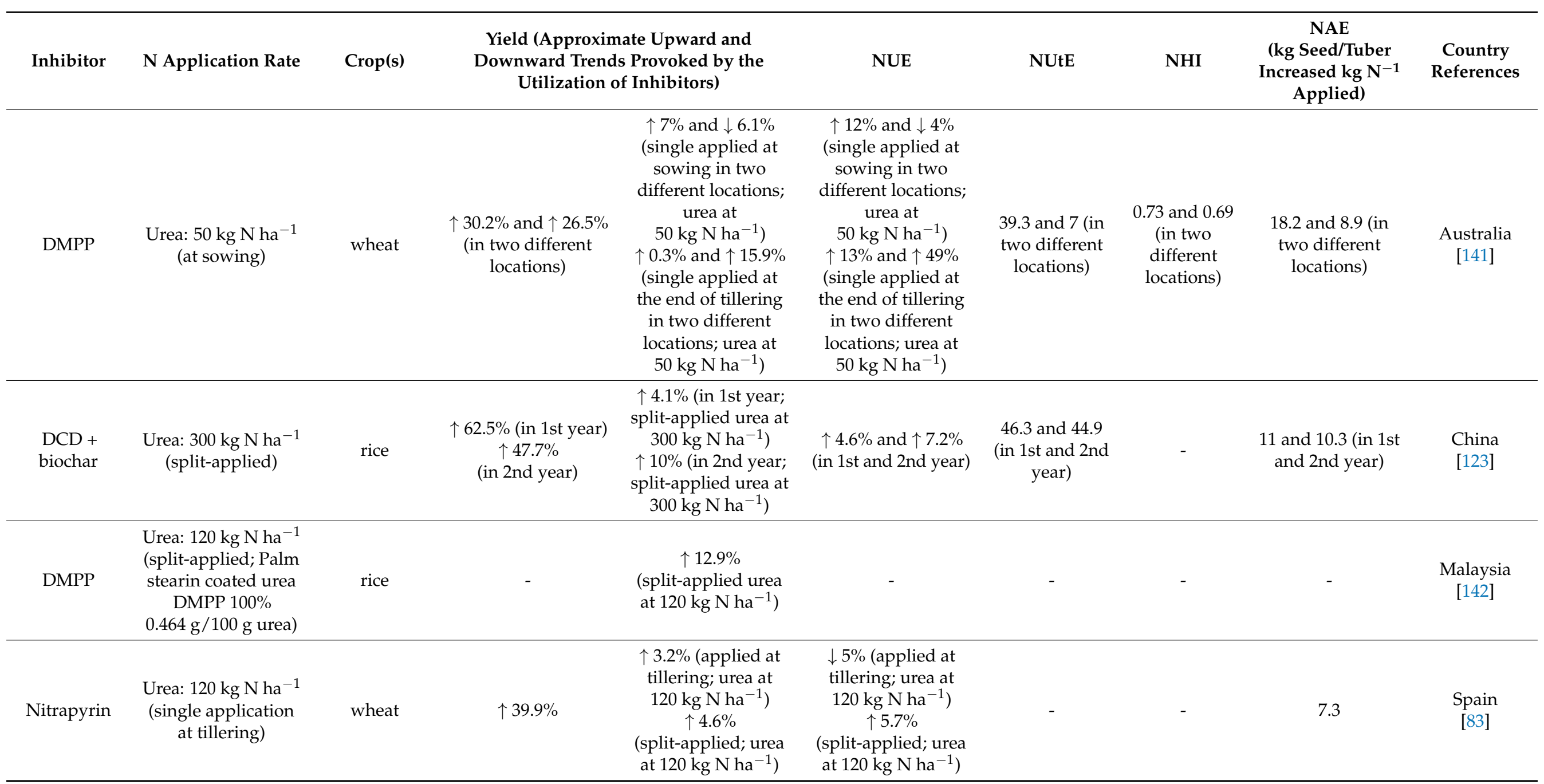


Table 1. Cont.

\begin{tabular}{|c|c|c|c|c|c|c|c|c|c|}
\hline Inhibitor & N Application Rate & Crop(s) & $\begin{array}{c}\text { Yield (Approxir } \\
\text { Downward Tren } \\
\text { Utilization }\end{array}$ & $\begin{array}{l}\text { ate Upward and } \\
\text { Provoked by the } \\
\text { Inhibitors) }\end{array}$ & NUE & NUtE & NHI & $\begin{array}{c}\text { NAE } \\
\text { (kg Seed/Tuber } \\
\text { Increased kg N }{ }^{-1} \\
\text { Applied) }\end{array}$ & $\begin{array}{c}\text { Country } \\
\text { References }\end{array}$ \\
\hline DMPP & $\begin{array}{l}\text { Urea: } 300 \mathrm{~kg} \mathrm{~N} \mathrm{ha}{ }^{-1} \\
\text { (split-applied 50:50) }\end{array}$ & wheat & $\uparrow 88.6 \%$ & $\begin{array}{c}\uparrow 6.4 \% \text { (urea at } 300 \\
\mathrm{~kg} \mathrm{~N} \mathrm{ha}^{-1} \\
\text { split-applied) }\end{array}$ & $\begin{array}{c}\uparrow 2.4 \% \text { (three-year } \\
\text { average) }\end{array}$ & - & - & 10.3 & $\begin{array}{l}\text { China } \\
\text { [139] }\end{array}$ \\
\hline DMPP & $\begin{array}{l}\text { Ammonium } \\
\text { sulphate: } \\
120 \mathrm{~kg} \mathrm{~N} \mathrm{ha}^{-1}\end{array}$ & wheat & $\uparrow 14.4 \%$ & $\begin{array}{c}\uparrow 6.3 \% \text { (ammonium } \\
\text { sulphate at } \\
120 \mathrm{~kg} \mathrm{~N} \mathrm{ha}^{-1} \text { ) }\end{array}$ & $\uparrow 3.6 \%$ & - & - & 3.2 & $\begin{array}{l}\text { Iran } \\
{[101]}\end{array}$ \\
\hline \multicolumn{10}{|c|}{$\begin{array}{l}\text { Percentages are presented as average values with one decimal of the increase or decrease in yield and several indexes. Data is derived from tables, figures and graphs from literature and indicate approximate } \\
\text { values as mean of sites/years/replications. Increases or decreases are not always statistically significant at different significance level, depending on study level. Nitrogen efficiency values were either calculated } \\
\text { or estimated as differences of percentages. }\end{array}$} \\
\hline Inhibitor & N Application Rate & Crop(s) & $\begin{array}{c}\text { Yield (Approxir } \\
\text { Downward Tren } \\
\text { Utilization }\end{array}$ & $\begin{array}{l}\text { ate Upward and } \\
\text { Provoked by the } \\
\text { Inhibitors) }\end{array}$ & NUE & NUtE & NHI & $\begin{array}{c}\text { NAE (kg } \\
\text { Seed/Tuber } \\
\text { Increased kg N-1 } \\
\text { Applied) }\end{array}$ & $\begin{array}{l}\text { Country } \\
\text { References }\end{array}$ \\
\hline \multicolumn{2}{|c|}{ Urease inhibitors (UI) } & & $\begin{array}{l}\text { Compared to } \\
\text { unfertilized control }\end{array}$ & $\begin{array}{c}\text { Compared to } \\
\text { fertilized control } \\
\text { without inhibitors }\end{array}$ & $\begin{array}{c}\text { Compared to } \\
\text { fertilized control } \\
\text { without inhibitors }\end{array}$ & & & $\begin{array}{l}\text { Compared to } \\
\text { unfertilized } \\
\text { control }\end{array}$ & \\
\hline NBPT & Urea: 96 kg N ha ${ }^{-1}$ & maize & $\uparrow 203 \%$ or 3.03 -fold & $\begin{array}{l}\uparrow 49 \%(\text { urea at } \\
120 \mathrm{~kg} \mathrm{~N} \mathrm{ha}^{-1} \text { ) }\end{array}$ & $\uparrow 45 \%$ & - & - & - & $\begin{array}{c}\text { Malaysia } \\
\text { [113] }\end{array}$ \\
\hline NBPT & $\begin{array}{c}\text { Urea: } \\
178.4 \mathrm{~kg} \mathrm{~N} \mathrm{ha}^{-1}\end{array}$ & maize & $\begin{array}{c}\uparrow 85 \% \text { (urea: } \\
28.4 \mathrm{~kg} \mathrm{~N} \mathrm{ha}^{-1} \text { ) }\end{array}$ & $\begin{array}{c}\uparrow 5.6 \% \text { (urea at } \\
178.4 \mathrm{~kg} \mathrm{~N} \mathrm{ha}^{-1} \text { ) }\end{array}$ & - & - & - & 29.4 & $\begin{array}{l}\text { Canada } \\
\text { [115] }\end{array}$ \\
\hline
\end{tabular}


Table 2. Cont.

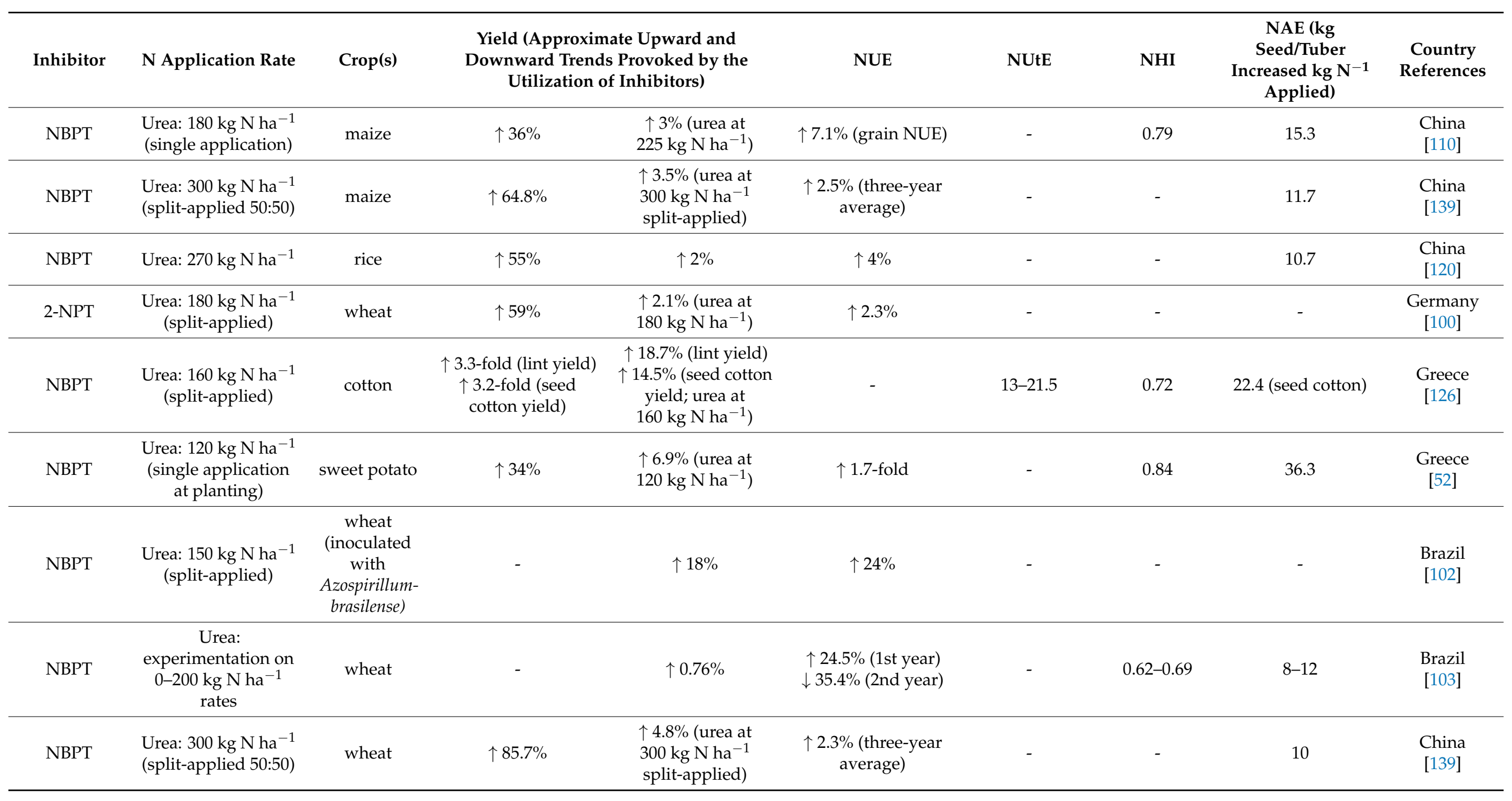


Table 2. Cont.

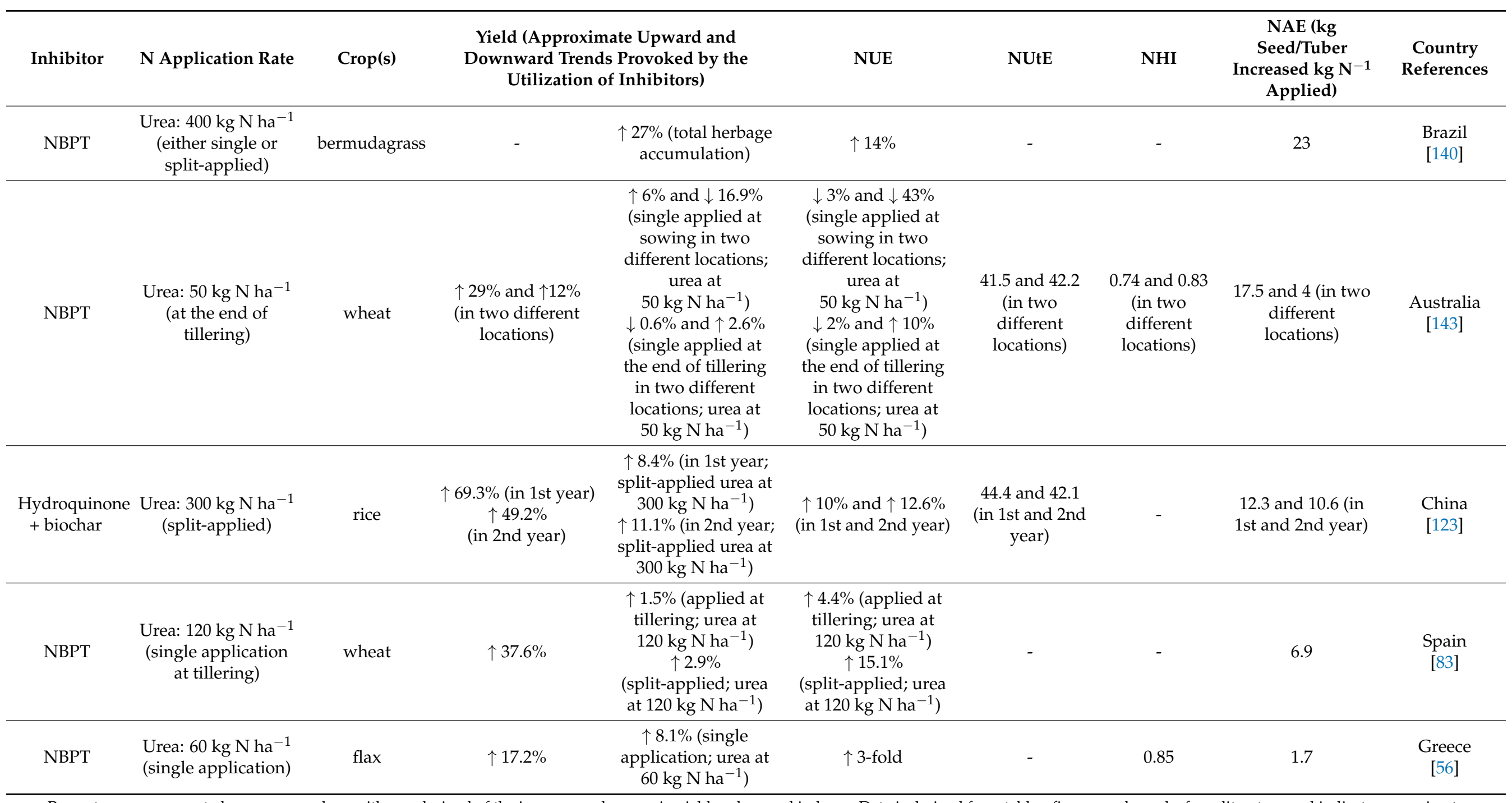

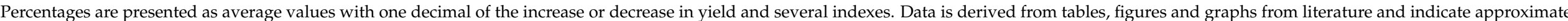

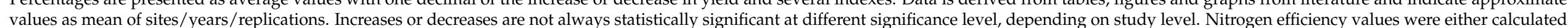
or estimated as differences of percentages. 
Table 3. Nitrification and urease inhibitors use in different crops/regions/rates and their association with Nitrogen efficiency indices.

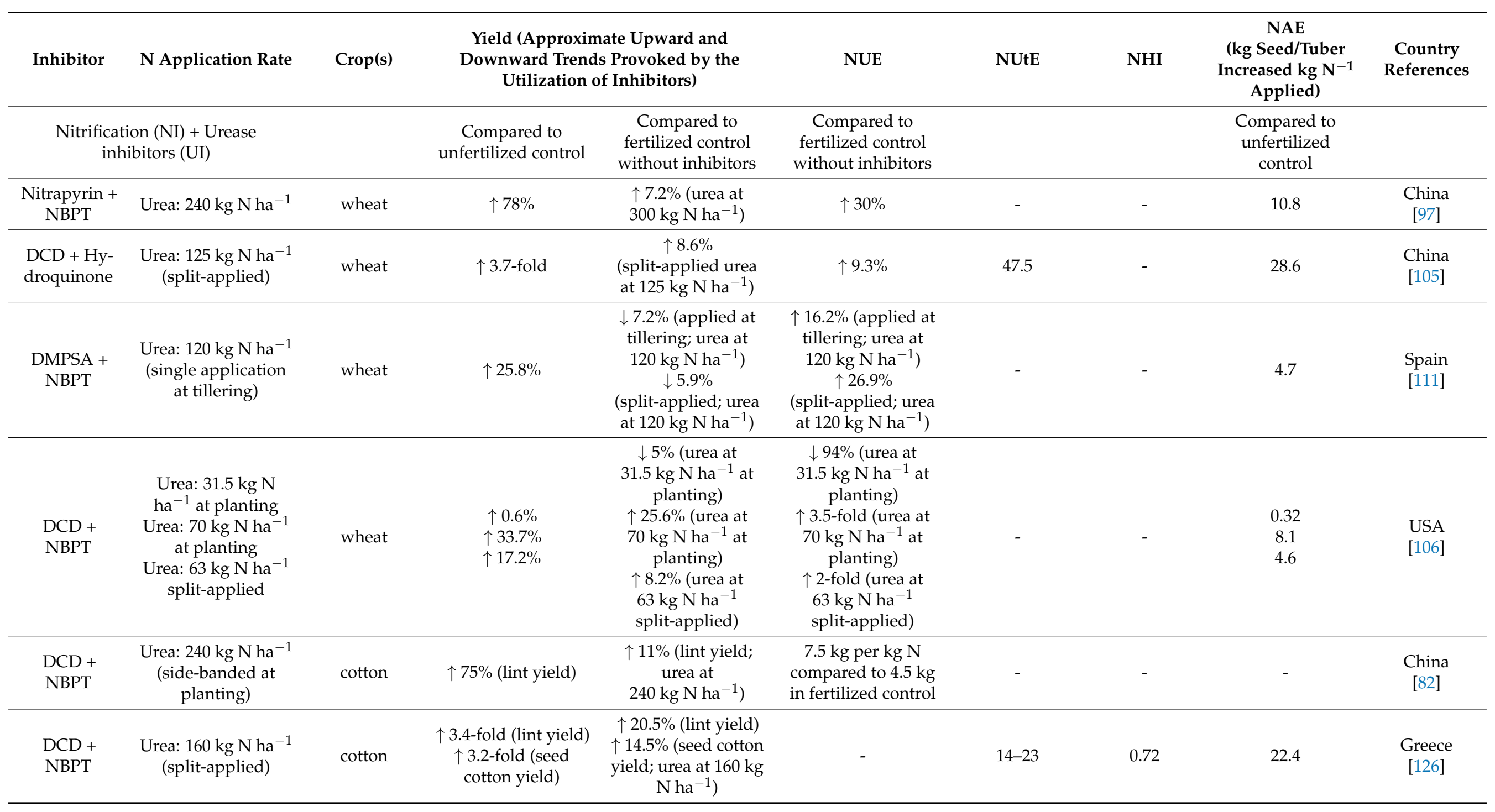


Table 3. Cont.

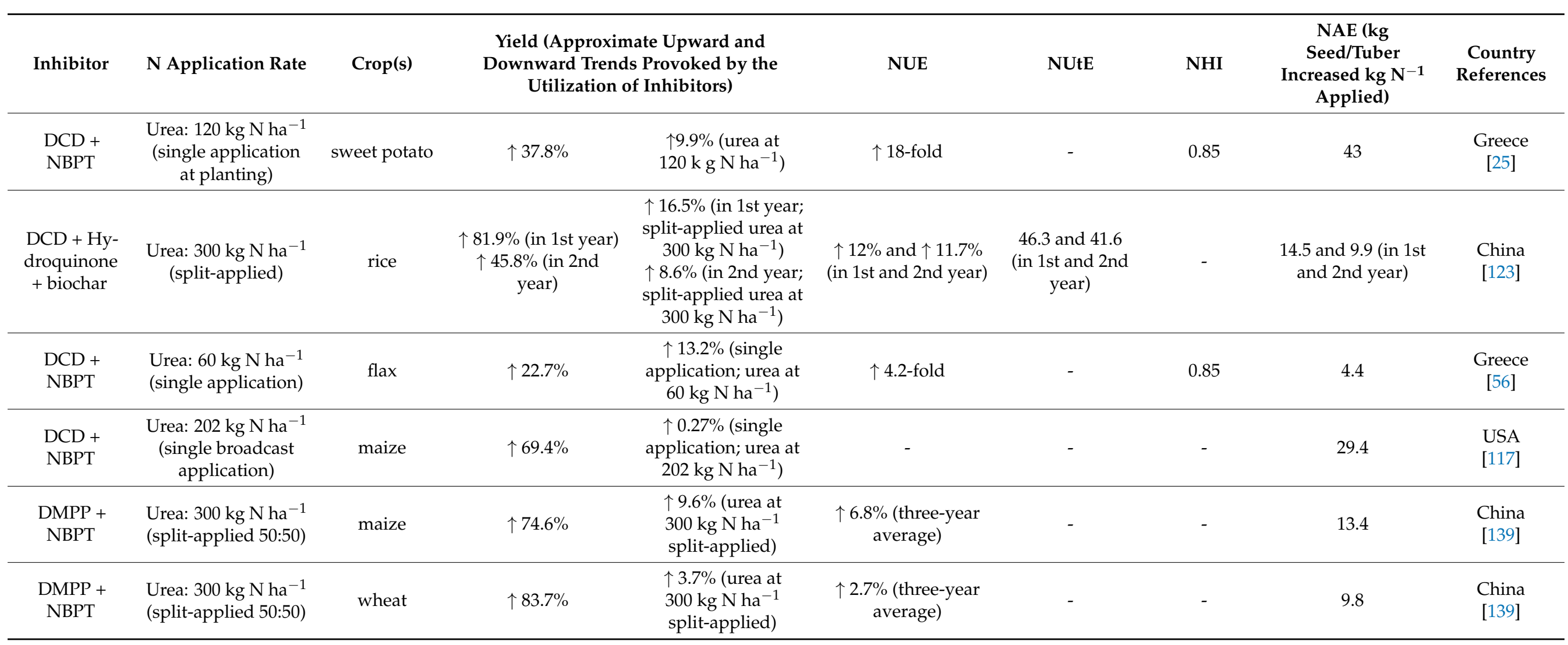

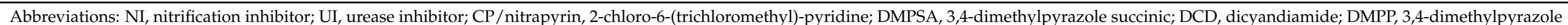

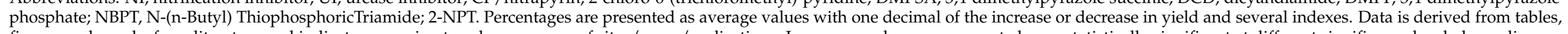

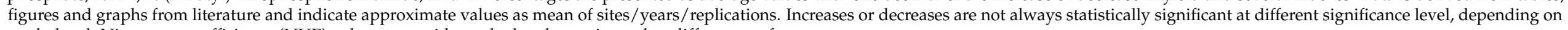
study level. Nitrogen use efficiency (NUE) values were either calculated or estimated as differences of percentages. 


\section{Conclusions}

The potentiality of urease and nitrification inhibitors to increase nitrogen use efficiency from the mass application of agricultural fertilizers has long been identified. Fertilizer inhibitors are considered an integral part of the fertilizer market. However, the undefined and non-optimal growth stage of crops that demand nitrogen supply, the irregular or misplaced fertilization, and the use of non-appropriate fertilizer products raise operation costs and reduce the net profit to farmers. Therefore, decision-making on the field level should be based upon ratios and indexes. A key to increasing yields may be towards later nitrogen uptake in the growing cycle and also rise of nitrogen storage in aboveground parts of plants. Soil nitrogen losses by leaching, along with competition for photosynthesis within the plant during seed growth, require increased nitrogen storage and transport from plant tissues to seeds in large quantities. Nitrogen indicators are an indispensable tool for assessing the percentage or amount of nitrogen stored in plants or not. $\mathrm{N}$ management indexes could describe better the large scene, indicating the positive or negative effects of inhibitors in various agronomic situations. Nitrogen Use Efficiency (NUE) is widely used to show the nitrogen recovery efficiency of all crops depending on many factors, either environmental or agricultural. Nitrogen Utilization Efficiency (NUtE) is a rather less common index; however, it could be quite useful in cotton and cereals to show the amount of seed/lint or produced dry matter concerning total N plant uptake. NUtE revealed if applied nitrogen is stoked to the product of each crop (seed, lint, etc.) or remains at the above-ground part of the plant. Nitrogen Agronomic Efficiency (NAE) is particularly important to optimize the nitrogen fertilization rates and predict the increase of seed yield per kilo of $\mathrm{N}$ fertilizer, with yield gains for unit of $\mathrm{N}$ fertilizer applied. This index is ideal for the estimation of required fertilizer. This index is useful for all grain-producing plant (cereals, legumes, pseudocereals, and industrial hemp). Additionally, NAE could be used in many novel crops such as sweet potato. Finally, Nitrogen Harvest Index (NHI) is quite important for wheat and other crops, where protein content and yield need to be calculated. NHI and N yield is needed in crops in which nitrogen absorption, and therefore protein, is essential throughout the whole plant, such as silage crops. However, the farmer determines the final use of these indexes since different trade end-use of the final product requires diverse nitrogen allocation. For this purpose, seed/grain/tubers yield is better expressed through NUE, NUtE, and NAE indexes. NUE also expresses the allocated nitrogen in various plant tissues and is useful when the crop is cultivated for silage. On the contrary, NHI describes better the quality characteristics of the final products. This review inclines to the conclusion that $\mathrm{N}$-related indices have a fundamental role in $\mathrm{N}$ fertilization management for sustainable agricultural production systems. However, their prudent use requires an accurate assessment of these indices by eliminating knowledge management practices based on the production direction (target) of each crop along with the accurate interpretation of the respective indicators.

Author Contributions: Conceptualization, A.F. and I.K.; methodology, I.K., A.F., A.T., P.P. and I.S.T.; validation, I.K., A.E., N.K., I.R. and I.S.T.; formal analysis, I.K., A.F., A.T. and A.E.; investigation, I.K., A.F., A.T., A.M., I.R. and A.E.; data curation, A.F., A.M. and A.K.; writing original draft preparation, A.F., A.T., A.K., A.M. and I.K.; writing, review, and editing, A.F., A.T., A.K., M.K.D., A.M. and I.K.; visualization, I.K., A.F., A.T. and I.S.T.; supervision, I.K., A.E., I.S.T. and P.P.; project administration, I.K. All authors have read and agreed to the published version of the manuscript.

Funding: This research received no external funding.

Institutional Review Board Statement: Not applicable.

Informed Consent Statement: Not applicable.

Data Availability Statement: The data presented in this study are available on request from the corresponding author.

Conflicts of Interest: The authors declare no conflict of interest. 


\begin{abstract}
Abbreviations
$\mathrm{N}$, nitrogen; NI, nitrification inhibitor; UI, urease inhibitor; $\mathrm{CP} /$ nitrapyrin, 2-chloro-6-(trichloromethyl)pyridine; DMPSA, 3,4-dimethylpyrazole succinic; DCD, dicyandiamide; DMPP, 3,4-dimethylpyrazole phosphate; NBPT, N-(n-Butyl) ThiophosphoricTriamide; 2-NPT; NUE, Nitrogen Use Efficiency; NUtE, Nitrogen Utilization Efficiency; NAE, Nitrogen Agronomic Efficiency; NHI, Nitrogen Harvest Index.
\end{abstract}

\title{
References
}

1. Trostle, R. Global Agricultural Supply and Demand: Factors Contributing to the Recent Increase in Food Commodity Prices; Diane Publishing; United States Department of Agriculture: Washington, DC, USA, 2010.

2. Hertel, T.W. The global supply and demand for agricultural land in 2050: A perfect storm in the making? Am. J. Agric. Econ. 2011, 93, 259-275. [CrossRef]

3. Valizadeh, N.; Bijani, M. Agricultural Research: Applications and Future Orientations. In Zero Hunger; Springer: Cham, Switzerland, 2020; pp. 71-79. [CrossRef]

4. Alexandratos, N.; Bruinsma, J. World Agriculture Towards 2030/2050: The 2012 Revision; ESA Working Paper No. 12-03; Global Perspective Studies Unit, Food and Agriculture Organization of the United Nations: Rome, Italy, 2012. [CrossRef]

5. Tilman, D.; Cassman, K.G.; Matson, P.A.; Naylor, R.; Polasky, S. Agricultural sustainability and intensive production practices. Nature 2002, 418, 671-677. [CrossRef]

6. Lassaletta, L.; Billen, G.; Grizzetti, B.; Anglade, J.; Garnier, J. 50 year trends in nitrogen use efficiency of world cropping systems: The relationship between yield and nitrogen input to cropland. Environ. Res. Lett. 2014, 9, 105011. [CrossRef]

7. Gastal, F.; Lemaire, G.; Durand, J.L.; Louarn, G. Quantifying crop responses to nitrogen and avenues to improve nitrogen-use efficiency. In Crop Physiology, 2nd ed.; Sandras, V.O., Calderini, D.F., Eds.; Academic Press: Cambridge, MA, USA, 2015; pp. 161-206. [CrossRef]

8. Aulakh, M.S.; Malhi, S.S. Interactions of nitrogen with other nutrients and water: Effect on crop yield and quality, nutrient use efficiency, carbon sequestration, and environmental pollution. Adv. Agron. 2005, 86, 341-409. [CrossRef]

9. Sutton, M.A.; Bleeker, A.; Howard, C.M.; Bekunda, M.; Grizzetti, B.; de Vries, W.; van Grinsven, H.J.M.; Abrol, Y.P.; Adhya, T.K.; Billen, G.; et al. Our Nutrient World: The Challenge to Produce More Food E Energy with Less Pollution; NERC/Centre for Ecology \& Hydrology: Edinburgh, Scotland, UK, 2013.

10. Savci, S. Investigation of effect of chemical fertilizers on environment. Apcbee Proc. 2012, 1, 287-292. [CrossRef]

11. Khan, M.N.; Mohammad, F. Eutrophication: Challenges and solutions. In Eutrophication: Causes, Consequences and Control; Springer: Dordrecht, The Netherlands, 2014; pp. 1-15. [CrossRef]

12. Neset, T.S.S.; Bader, H.P.; Scheidegger, R.; Lohm, U. The flow of phosphorus in food production and consumption-Linköping, Sweden, 1870-2000. Sci. Total Environ. 2008, 396, 111-120. [CrossRef] [PubMed]

13. Han, Y.; Fan, Y.; Yang, P.; Wang, X.; Wang, Y.; Tian, J.; Xu, L.; Wang, C. Net anthropogenic nitrogen inputs (NANI) index application in Mainland China. Geoderma 2014, 213, 87-94. [CrossRef]

14. Hickey, L.T.; Hafeez, A.N.; Robinson, H.; Jackson, S.A.; Leal-Bertioli, S.C.; Tester, M.; Gao, C.; Godwin, I.D.; Hayes, B.J.; Wulff, B.B.H. Breeding crops to feed 10 billion. Nat. Biotechnol. 2019, 37, 744-754. [CrossRef]

15. Fischer, E.M.; Sedláček, J.; Hawkins, E.; Knutti, R. Models agree on forced response pattern of precipitation and temperature extremes. Geophys. Res. Lett. 2014, 41, 8554-8562. [CrossRef]

16. McArthur, J.W.; McCord, G.C. Fertilizing growth: Agricultural inputs and their effects in economic development. J. Dev. Econ. 2017, 127, 133-152. [CrossRef] [PubMed]

17. Soumare, A.; Diedhiou, A.G.; Thuita, M.; Hafidi, M.; Ouhdouch, Y.; Gopalakrishnan, S.; Kouisni, L. Exploiting Biological Nitrogen Fixation: A Route Towards a Sustainable Agriculture. Plants 2020, 9, 1011. [CrossRef] [PubMed]

18. Snyder, C.S. Enhanced nitrogen fertiliser technologies support the ' $4 \mathrm{R}$ 'concept to optimise crop production and minimise environmental losses. Soil Res. 2017, 55, 463-472. [CrossRef]

19. Gregorich, E.G.; Turchenek, L.W.; Carter, M.R.; Angers, D.A. Soil and Environmental Science Dictionary, 1st ed.; CRC Press: Boca Raton, FL, USA, 2001. [CrossRef]

20. Sharma, L.K.; Bali, S.K. A review of methods to improve nitrogen use efficiency in agriculture. Sustainability $2018,10,51$. [CrossRef]

21. Trenkel, M.E. Slow- and Controlled-Release and Stabilized Fertilizers: An Option for Enhancing Nutrient Use Efficiency in Agriculture, 2nd ed.; International Fertilizer Industry Association (IFA): Paris, France, 2010.

22. Fu, J.; Wang, C.; Chen, X.; Huang, Z.; Chen, D. Classification research and types of slow controlled release fertilizers (SRFs) used-a review. Commun. Soil Sci. Plant Anal. 2018, 49, 2219-2230. [CrossRef]

23. Association of American Plant Food Control Officials-AAPFCO. Official Documents 57; AAPFCO: West Lafayette, IN, USA, 1997.

24. Yamamoto, C.F.; Pereira, E.I.; Mattoso, L.H.C.; Mattoso, T.; Ribeiro, C. Slow release fertilizers based on urea/urea-Formaldehyde polymer nanocomposites. Chem. Eng. J. 2016, 287, 390-397. [CrossRef]

25. Kakabouki, I.; Togias, T.; Folina, A.E.; Karydogianni, S.; Zisi, C.; Bilalis, D. Evaluation of yield and nitrogen utilisation with urease and nitrification inhibitors in sweet potato crop (Ipomoea batatas L.). Folia Hortcult. 2020, 32, 147-157. [CrossRef]

26. Oertli, J.J. Controlled-release fertilizers. Fertil. Res. 1980, 1, 103-123. [CrossRef] 
27. Rudmin, M.; Banerjee, S.; Makarov, B. Evaluation of the effects of the application of glauconitic fertilizer on oat development: A two-year field-based investigation. Agronomy 2020, 10, 872. [CrossRef]

28. Sempeho, S.I.; Kim, H.T.; Mubofu, E.; Hilonga, A. Meticulous Overview on the Controlled Release Fertilizers. Adv. Chem. 2014, 1-16. [CrossRef]

29. Al-Rawajfeh, A.E.; Alrbaihat, M.R.; AlShamaileh, E.M. Characteristics and types of slow-and controlled-release fertilizers. In Controlled Release Fertilizers for Sustainable Agriculture, 1st ed.; Lewu, F.B., Volova, T., Sabu, T., Rakhimol, R.K., Eds.; Academic Press: Cambridge, MA, USA, 2020; pp. 57-78.

30. Van Eerd, L.L. Use of a nitrogen budget to predict nitrogen losses in processing butternut squash with different nitrogen fertilization strategies. HortScience 2010, 45, 1734-1740. [CrossRef]

31. Congreves, K.A.; Van Eerd, L.L. Nitrogen cycling and management in intensive horticultural systems. Nutr. Cycl. Agroecosyst. 2015, 102, 299-318. [CrossRef]

32. Romero, C.M.; Engel, R.E.; Chen, C.; Wallander, R.; Jones, C.A. Late-fall, winter, and spring broadcast applications of urea to no-till winter wheat II. Fertilizer N recovery, yield, and protein as affected by NBPT. Soil Sci. Soc. Am. J. 2017, 81, 331-340. [CrossRef]

33. Cox, M.C.; Qualset, C.O.; Rains, D.W. Genetic variation for nitrogen assimilation and translocation in wheat. I. Dry matter and nitrogen accumulation. Crop. Sci. 1985, 25, 430-435. [CrossRef]

34. Papakosta, D.K.; Gagianas, A.A. Nitrogen and dry matter accumulation, remobilization, and losses for Mediterranean wheat during grain filling. Agron. J. 1991, 83, 864-870. [CrossRef]

35. Panel, E.N.E. Nitrogen Use Efficiency (NUE) an Indicator for the Utilization of Nitrogen in Food Systems; Wageningen University, Alterra: Wageningen, The Netherlands, 2015.

36. Papangkorn, J.; Isaraphan, C.; Phinhongthong, S.; Opaprakasit, M.; Opaprakasit, P. Controlled-release material for urea fertilizer from polylactic acid. Adv. Mater. Res. 2008, 55, 897-900. [CrossRef]

37. Artola, E.; Cruchaga, S.; Ariz, I.; Moran, J.F.; Garnica, M.; Houdusse, F.; Garcia-Mina, J.M.; Ignacio, I.; Lasa, B.; Aparicio-Tejo, P.M. Effect of N-(n-butyl) thiophosphorictriamide on urea metabolism and the assimilation of ammonium by Triticum aestivum L. Plant Growth Regul. 2011, 63, 73-79. [CrossRef]

38. Cantarella, H.; Otto, R.; Soares, J.R.; de Brito Silva, A.G. Agronomic efficiency of NBPT as a urease inhibitor: A review. J. Adv. Res. 2018, 13, 19-27. [CrossRef]

39. Upadhyay, L.S.B. Urease inhibitors: A review. Indian J. Biotechnol. 2012, 11, 381-388.

40. Saggar, S.; Singh, J.; Giltrap, D.L.; Zaman, M.; Luo, J.; Rollo, M.; Kim, D.-G.; Rys, G.; Van der Weerden, T.J. Quantification of reductions in ammonia emissions from fertiliser urea and animal urine in grazed pastures with urease inhibitors for agriculture inventory: New Zealand as a case study. Sci. Total Environ. 2013, 465, 136-146. [CrossRef]

41. Byrne, M.P.; Tobin, J.T.; Forrestal, P.J.; Danaher, M.; Nkwonta, C.G.; Richards, K.; Cummins, E.; Hogan, S.A.; O'Callaghan, T.F. Urease and Nitrification Inhibitors-As Mitigation Tools for Greenhouse Gas Emissions in Sustainable Dairy Systems: A Review. Sustainability 2020, 12, 6018. [CrossRef]

42. Singh, A.; Kumar, A.; Jaswal, A.; Singh, M.; Gaikwad, D. Nutrient use efficiency concept and interventions for improving nitrogen use efficiency. Plant Arch. 2018, 18, 1015-1023.

43. Kafarski, P.; Talma, M. Recent advances in design of new urease inhibitors: A review. J. Adv. Res. 2018, 13, 101-112. [CrossRef]

44. Singh, J.; Bolan, N.S.; Saggar, S.; Zaman, M. The role of inhibitors in controlling the bioavailability and losses of nitrogen. In Chemical Bioavailability in Terrestrial Environment, 1st ed.; Naidu, R., Ed.; Elsevier: Amsterdam, The Netherlands, 2008 ; pp. 329-362.

45. Xu, J.; Liao, L.; Tan, J.; Shao, X. Ammonia volatilization in gemmiparous and early seedling stages from direct seeding rice fields with different nitrogen management strategies: A pots experiment. Soil Tillage Res. 2013, 126, 169-176. [CrossRef]

46. Subbarao, G.V.; Ito, O.; Sahrawat, K.L.; Berry, W.L.; Nakahara, K.; Ishiwawa, T.; Watanabe, T.; Suenaga, K.; Rondon, M.; Rao, I.M. Scope and strategies for regulation of nitrification in agricultural systems-challenges and opportunities. Crit. Rev. Plant Sci. 2006, 25, 303-335. [CrossRef]

47. Snyder, C.S.; Davidson, E.A.; Smith, P.; Venterea, R.T. Agriculture: Sustainable crop and animal production to help mitigate nitrous oxide emissions. Curr. Opin. Environ. Sustain. 2014, 9-10, 46-54. [CrossRef]

48. Soares, J.R.; Cassman, N.A.; Kielak, A.M.; Pijl, A.; Carmo, J.B.; Lourenço, K.S.; Kuramae, E.E. Nitrous oxide emission related to ammonia-oxidizing bacteria and mitigation options from $\mathrm{N}$ fertilization in a tropical soil. Sci. Rep. 2016, 6, 30349. [CrossRef]

49. Pan, B.; Lam, S.K.; Mosier, A.; Luo, Y.; Chen, D. Ammonia volatilization from synthetic fertilizers and its mitigation strategies: A global synthesis. Agric. Ecosyst. Environ. 2016, 232, 283-289. [CrossRef]

50. Yang, Y.; Zhang, M.; Li, Y.; Fan, X.; Geng, Y. Controlled-Release Urea Commingled with Rice Seeds Reduced Emission of Ammonia and Nitrous Oxide in Rice Paddy Soil. J. Environ. Qual. 2013, 42, 1661-1673. [CrossRef]

51. Soares, J.R.; Cantarella, H.; Menegale, M.L.C. Ammonia volatilization losses from surface-applied urea with urease and nitrifications inhibitors. Soil Biol. Biochem. 2012, 52, 82-89. [CrossRef]

52. Kakabouki, I.; Folina, A.E.; Zisi, C.; Karydogianni, S. Fertilization expression via nitrogen indices in soybean crop under two system tillage. Not. Bot. Horti Agrobot. Cluj-Napoca 2020, 48, 799-813. [CrossRef]

53. Zerulla, W.; Barth, T.; Dressel, J.; Erhardt, K.; von Locquenghien, K.H.; Pasda, G.; Rädle, M.; Wissemeier, A. 3, 4-Dimethylpyrazole phosphate (DMPP)-a new nitrification inhibitor for agriculture and horticulture. Biol. Fertil. Soils 2001, 34, 79-84. [CrossRef] 
54. Frame, W. Ammonia volatilization from urea treated with NBPT and two nitrification inhibitors. Agron. J. 2017, 109, 1-10. [CrossRef]

55. Gioacchini, P.; Nastri, A.; Marzadori, C.; Giovannini, C.; Antisari, L.V.; Gessa, C. Influence of urease and nitrification inhibitors on $\mathrm{N}$ losses from soils fertilized with urea. Biol. Fertil. Soils 2002, 36, 129-135. [CrossRef]

56. Kakabouki, I.; Karydogianni, S.; Zisi, C.; Folina, A.E. Effect of fertilization with N-inhibitors on root and crop development of flaxseed crop (Linumusitatissimum L.). AGRIVITA J. Agric. Sci. 2020, 42. [CrossRef]

57. Moll, R.H.; Kamprath, E.J.; Jackson, W.A. Analysis and interpretation of factors which contribute to efficiency of nitrogen utilization 1. Agron. J. 1982, 74, 562-564. [CrossRef]

58. Goulding, K.; Jarvis, S.; Whitmore, A. Optimizing nutrient management for farm systems. Philos. Trans. R. Soc. B Biol Sci. 2008, 363, 667-680. [CrossRef]

59. Merrill, A.L.; Watt, B.K. Energy value of foods: Basis and derivation. In Agriculture Handbook; United States Department of Agriculture: Washington, DC, USA, 1973; p. 74.

60. Ye, Q.; Zhang, H.; Wei, H.; Zhang, Y.; Wang, B.; Xia, K.; Huo, Z.; Dai, Q.; Xu, K. Effects of nitrogen fertilizer on nitrogen use efficiency and yield of rice under different soil conditions. Front. Agric. China 2007, 1, 30-36. [CrossRef]

61. Craswell, E.T.; Godwin, D.C. The Efficiency of Nitrogen Fertilizers Applied to Cereals Grown in Different Climates; No. REP-3326; CIMMYT: El Batán, Mexico, 1984.

62. Raza, S.; Zhou, J.; Aziz, T.; Afzal, M.R.; Ahmed, M.; Javaid, S.; Chen, Z. Piling up reactive nitrogen and declining nitrogen use efficiency in Pakistan: A challenge not challenged (1961-2013). Environ. Res. Lett. 2018, 13, 034012. [CrossRef]

63. Shi, Z.; Li, D.; Jing, Q.; Cai, J.; Jiang, D.; Cao, W.; Dai, T. Effects of nitrogen applications on soil nitrogen balance and nitrogen utilization of winter wheat in a rice-wheat rotation. Field Crop. Res. 2012, 127, 241-247. [CrossRef]

64. Lian, H.; Qin, C.; He, Z.; Niu, J.; Zhang, C.; Sang, T.; Li, H.; Zhang, S. A synergistic increase in water and nitrogen use efficiencies in winter wheat cultivars released between the 1940s and the 2010s for cultivation in the drylands of the shaanxi Province in China. Agric. Water Manag. 2020, 240, 106308. [CrossRef]

65. Kumar, R.; Prakash, N.R.; Padhan, B.K. An inside into the nitrogen use efficiency and its importance in crop production. J. Pharmacogn. Phytochem. 2019, 8, 2652-2657.

66. Hocking, M.D.; Reynolds, J.D. Nitrogen uptake by plants subsidized by Pacific salmon carcasses: A hierarchical experiment. Can. J. For. Res. 2012, 42, 908-917. [CrossRef]

67. Chilundo, M.; Joel, A.; Wesström, I.; Brito, R.; Messing, I. Effects of reduced irrigation dose and slow release fertiliser on nitrogen use efficiency and crop yield in a semi-arid loamy sand. Agric. Water Manag. 2016, 168, 68-77. [CrossRef]

68. Hao, Q.N.; Zhou, X.A.; Ai, H.S.; Wang, C.; Zhou, R.; Chen, S.L. Identification of genes associated with nitrogen-use efficiency by genome-wide transcriptional analysis of two soybean genotypes. BMC Genome 2011, 12, 525. [CrossRef]

69. Attia, A.; Shapiro, C.; Kranz, W.; Mamo, M.; Mainz, M. Improved yield and nitrogen use efficiency of corn following soybean in irrigated sandy loams. Soil Sci. Soc. Am. J. 2015, 79, 1693-1703. [CrossRef]

70. López-Bellido, R.J.; López-Bellido, L. Efficiency of nitrogen in wheat under Mediterranean conditions: Effect of tillage, crop rotation and $\mathrm{N}$ fertilization. Field Crop. Res. 2001, 71,31-46. [CrossRef]

71. Ruisi, P.; Saia, S.; Badagliacca, G.; Amato, G.; Frenda, A.S.; Giambalvo, D.; Di Miceli, G. Long-term effects of no tillage treatment on soil $\mathrm{N}$ availability, $\mathrm{N}$ uptake, and $15 \mathrm{~N}$-fertilizer recovery of durum wheat differ in relation to crop sequence. Field Crop. Res. 2016, 189, 51-58. [CrossRef]

72. Lu, C.; Zhang, J.; Cao, P.; Hatfield, J.L. Are we getting better in using nitrogen? Variations in nitrogen use efficiency of two cereal crops across the United States. Earth's Future 2019, 7, 939-952. [CrossRef]

73. Cormier, F.; Faure, S.; Dubreuil, P.; Heumez, E.; Beauchêne, K.; Lafarge, S.; Praud, S.; Le Gouis, J. A multi-environmental study of recent breeding progress on nitrogen use efficiency in wheat (Triticum aestivum L.). Theor. Appl. Genet. 2013, 126, 3035-3048. [CrossRef]

74. Weih, M.; Hamnér, K.; Pourazari, F. Analyzing plant nutrient uptake and utilization efficiencies: Comparison between crops and approaches. Plant Soil 2018, 430, 7-21. [CrossRef]

75. Szumigalski, A.R.; Van Acker, R.C. Nitrogen yield and land use efficiency in annual sole crops and intercrops. Agron. J. 2006, 98, 1030-1040. [CrossRef]

76. Haile, D.; Nigussie, D.; Ayana, A. Nitrogen use efficiency of bread wheat: Effects of nitrogen rate and time of application. J. Soil Sci. Plant Nutr. 2012, 12, 389-410. [CrossRef]

77. Min, J.; Sun, H.; Kronzucker, H.J.; Wang, Y.; Shi, W. Comprehensive assessment of the effects of nitrification inhibitor application on reactive nitrogen loss in intensive vegetable production systems. Agric. Ecosyst. Environ. 2021, 307, 107227. [CrossRef]

78. Abalos, D.; Jeffery, S.; Sanz-Cobena, A.; Guardia, G.; Vallejo, A. Meta-analysis of the effect of urease and nitrification inhibitors on crop productivity and nitrogen use efficiency. Agric. Ecosyst. Environ. 2014, 189, 136-144. [CrossRef]

79. Ding, W.X.; Chen, Z.M.; Yu, H.Y.; Luo, J.F.; Yoo, G.Y.; Xiang, J.; Zhang, H.J.; Yuan, J.J. Nitrous oxide emission and nitrogen use efficiency in response to nitrophosphate, $\mathrm{N}$-(n-butyl) thiophosphorictriamide and dicyandiamide of a wheat cultivated soil under sub-humid monsoon conditions. Biogeosciences 2015, 12, 803-815. [CrossRef]

80. Feng, J.; Li, F.; Deng, A.; Feng, X.; Fang, F.; Zhang, W. Integrated assessment of the impact of enhanced-efficiency nitrogen fertilizer on N2O emission and crop yield. Agric. Ecosyst. Environ. 2016, 231, 218-228. [CrossRef] 
81. Li, T.; Zhang, W.; Yin, J.; Chadwick, D.; Norse, D.; Lu, Y.; Liu, X.; Chen, X.; Zhang, F.; Powlson, D.; et al. Enhanced-efficiency fertilizers are not a panacea for resolving the nitrogen problem. Glob. Chang. Biol. 2018, 24, e511-e521. [CrossRef] [PubMed]

82. Li, Y.; Gao, X.; Tenuta, M.; Gui, D.; Li, X.; Xue, W.; Zeng, F. Enhanced efficiency nitrogen fertilizers were not effective in reducing $\mathrm{N} 2 \mathrm{O}$ emissions from a drip-irrigated cotton field in arid region of Northwestern China. Sci. Total Environ. 2020, 748, 141543. [CrossRef]

83. Guardia, G.; Sanz-Cobena, A.; Sanchez-Martín, L.; Fuertes-Mendizábal, T.; González-Murua, C.; Álvarez, J.M.; Chadwick, D.; Vallejo, A. Urea-based fertilization strategies to reduce yield-scaled $\mathrm{N}$ oxides and enhance bread-making quality in a rainfed Mediterranean wheat crop. Agric. Ecosyst. Environ. 2018, 265, 421-431. [CrossRef]

84. Rose, T.J.; Wood, R.H.; Rose, M.T.; Van Zwieten, L. A re-evaluation of the agronomic effectiveness of the nitrification inhibitors DCD and DMPP and the urease inhibitor NBPT. Agric. Ecosyst. Environ. 2018, 252, 69-73. [CrossRef]

85. Abbasi, M.K.; Hina, M.; Tahir, M.M. Effect of Azadirachta indica (neem), sodium thiosulphate and calcium chloride on changes in nitrogen transformations and inhibition of nitrification in soil incubated under laboratory conditions. Chemosphere 2011, 82, 1629-1635. [CrossRef] [PubMed]

86. Upadhyay, R.K.; Tewari, S.K.; Patra, D.D. Natural nitrification inhibitors for higher nitrogen use efficiency, crop yield, and for curtailing global warming. J. Trop. Agric. 2011, 49, 19-24.

87. Migliorati, M.D.A.; Bell, M.J.; Grace, P.R.; Rowlings, D.W.; Scheer, C.; Strazzabosco, A. Assessing agronomic and environmental implications of different $\mathrm{N}$ fertilisation strategies in subtropical grain cropping systems on Oxisols. Nutr. Cycl. Agroecosyst. 2014, 100, 369-382. [CrossRef]

88. Li, T.; Zhang, X.; Gao, H.; Li, B.; Wang, H.; Yan, Q.; Ollenburger, M.; Zhang, W. Exploring optimal nitrogen management practices within site-specific ecological and socioeconomic conditions. J. Clean. Prod. 2019, 241, 118295. [CrossRef]

89. Janke, C.K.; Moody, P.; Bell, M.J. Three-dimensional dynamics of nitrogen from banded enhanced efficiency fertilizers. Nutr. Cycl. Agroecosyst. 2020, 118, 227-247. [CrossRef]

90. Souza, E.F.; Soratto, R.P.; Sandaña, P.; Venterea, R.T.; Rosen, C.J. Split application of stabilized ammonium nitrate improved potato yield and nitrogen-use efficiency with reduced application rate in tropical sandy soils. Field Crop. Res. 2020, $254,107847$. [CrossRef]

91. Linquist, B.A.; Liu, L.; van Kessel, C.; van Groenigen, K.J. Enhanced efficiency nitrogen fertilizers for rice systems: Meta-analysis of yield and nitrogen uptake. Field Crop. Res. 2013, 154, 246-254. [CrossRef]

92. Galindo, F.S.; Teixeira Filho, M.C.; Buzetti, S.; Pagliari, P.H.; Santini, J.M.; Alves, C.J.; Megda, M.M.; Nogueira, T.A.R.; Andreotti, M.; Arf, O. Maize yield response to nitrogen rates and sources associated with Azospirillumbrasilense. Agron. J. 2019, 111, 1985-1997. [CrossRef]

93. Cardenas, L.M.; Bhogal, A.; Chadwick, D.R.; McGeough, K.; Misselbrook, T.; Rees, R.M.; Thorman, R.E.; Watson, C.J.; Williams, J.R.; Smith, K.A.; et al. Nitrogen use efficiency and nitrous oxide emissions from five UK fertilised grasslands. Sci. Total Environ. 2019, 661, 696-710. [CrossRef]

94. Kubota, H.; Iqbal, M.; Quideau, S.; Dyck, M.; Spaner, D. Agronomic and physiological aspects of nitrogen use efficiency in conventional and organic cereal-based production systems. Renew. Agric. Food Syst. 2018, 33, 443-466. [CrossRef]

95. Hatfield, J.L.; Parkin, T.B. Enhanced efficiency fertilizers: Effect on agronomic performance of corn in Iowa. Agron. J. 2014, 106, 771-780. [CrossRef]

96. Shaviv, A.; Hagin, J.; Neumann, P.M. Effects of a nitrification inhibitor on efficiency of nitrogen utilization by wheat and millet. Commun. Soil Sci. Plant Anal. 1987, 18, 815-833. [CrossRef]

97. Tao, R.; Li, J.; Hu, B.; Shah, J.A.; Chu, G. A 2-year study of the impact of reduced nitrogen application combined with double inhibitors on soil nitrogen transformation and wheat productivity under drip irrigation. J. Sci. Food Agric. 2020. [CrossRef] [PubMed]

98. Guardia, G.; Gonzalez-Murua, C.; Fuertes-Mendizabal, T.; Vallejo, A. The scarcity and distribution of rainfall drove the performance (ie, mitigation of $\mathrm{N}$ oxide emissions, crop yield and quality) of calcium ammonium nitrate management in a wheat crop under rainfed semiarid conditions. Arch. Agron. Soil Sci. 2020, 66, 1827-1844. [CrossRef]

99. Recio, J.; Montoya, M.; Ginés, C.; Sanz-Cobena, A.; Vallejo, A.; Alvarez, J.M. Joint mitigation of NH3 and N2O emissions by using two synthetic inhibitors in an irrigated cropping soil. Geoderma 2020, 373, 114423. [CrossRef]

100. Rekowski, A.; Wimmer, M.A.; Hitzmann, B.; Hermannseder, B.; Hahn, H.; Zörb, C. Application of urease inhibitor improves protein composition and bread-baking quality of urea fertilized winter wheat. J. Plant Nutr. Soil Sci. 2020, 183, 260-270. [CrossRef]

101. Mousavi Shalmani, M.A.; Lakzian, A.; Khorassani, R.; Khavazi, K.; Zaman, M. Interaction of Different Wheat Genotypes and Nitrification Inhibitor 3, 4-Dimethylpyrazole Phosphate Using 15N Isotope Tracing Techniques. Commun. Soil Sci. Plant Anal. 2017, 48, 1247-1258. [CrossRef]

102. Galindo, F.S.; Teixeira Filho, M.C.M.; Buzetti, S.; Pagliari, P.H.; Santini, J.M.K. Can NBPT urease inhibitor in combination with Azospirillumbrasilense inoculation improve wheat development? Nutr. Cycl. Agroecosyst. 2020, 1-13. [CrossRef]

103. Galindo, F.S.; Teixeira Filho, M.C.M.; Buzetti, S.; Rodrigues, W.L.; Santini, J.M.K.; Alves, C.J. Nitrogen fertilisation efficiency and wheat grain yield affected by nitrogen doses and sources associated with Azospirillumbrasilense. Acta Agric. Scand. Sect. B Soil Plant Sci. 2019, 69, 606-617. [CrossRef]

104. Ercoli, L.; Masoni, A.; Pampana, S.; Mariotti, M.; Arduini, I. As durum wheat productivity is affected by nitrogen fertilisation management in Central Italy. Eur. J. Agron. 2013, 44, 38-45. [CrossRef] 
105. He, T.; Liu, D.; Yuan, J.; Luo, J.; Lindsey, S.; Bolan, N.; Ding, W. Effects of application of inhibitors and biochar to fertilizer on gaseous nitrogen emissions from an intensively managed wheat field. Sci. Total Environ. 2018, 628, 121-130. [CrossRef] [PubMed]

106. Adams, C.B.; Thapa, S.B.; Fan, Y.; Park, S. Agronomic and economic effects of two enhanced-efficiency urea fertilizer technologies on Southern Great Plains winter wheat. Agron. J. 2018, 110, 1097-1102. [CrossRef]

107. Liu, C.; Wang, K.; Zheng, X. Effects of nitrification inhibitors (DCD and DMPP) on nitrous oxide emission, crop yield and nitrogen uptake in a wheat-maize cropping system. Biogeosciences 2013, 10. [CrossRef]

108. Alonso-Ayuso, M.; Gabriel, J.L.; Quemada, M. Nitrogen use efficiency and residual effect of fertilizers with nitrification inhibitors. Eur. J. Agron. 2016, 80, 1-8. [CrossRef]

109. Barker, D.; Sawyer, J. Evaluation of nitrogen fertilizer additives for enhanced efficiency in corn on Iowa soils. Crop. Soils 2017, 50, 52-58. [CrossRef]

110. Liu, G.; Yang, Z.; Du, J.; He, A.; Yang, H.; Xue, G.; Zhang, Y. Adding NBPT to urea increases N use efficiency of maize and decreases the abundance of $\mathrm{N}$-cycling soil microbes under reduced fertilizer-N rate on the North China Plain. PLoS ONE 2020, 15, e0240925. [CrossRef]

111. Guardia, G.; Vallejo, A.; Cardenas, L.M.; Dixon, E.R.; García-Marco, S. Fate of 15N-labelled ammonium nitrate with or without the new nitrification inhibitor DMPSA in an irrigated maize crop. Soil Biol. Biochem. 2018, 116, 193-202. [CrossRef]

112. Shoji, S.; Delgado, J.; Mosier, A.; Miura, Y. Use of controlled release fertilizers and nitrification inhibitors to increase nitrogen use efficiency and to conserve air andwater quality. Commun. Soil Sci. Plant Anal. 2001, 32, 1051-1070. [CrossRef]

113. MohdZuki, M.M.; Sakimin, S.Z.; Yusop, M.K. N-(n-Butyl) ThiophosphoricTriamide (NBPT)-Coated Urea (NCU) Improved Maize Growth and Nitrogen Use Efficiency (NUE) in Highly Weathered Tropical Soil. Sustainability 2020, 12, 8780. [CrossRef]

114. Rinaldi, L.F.; Garcia, P.L.; Sermarini, R.A.; Trivelin, P.C.O. $15 \mathrm{~N}$-Urea efficiency in maize as influenced by humic substances and urease inhibitors treatments. Commun. Soil Sci. Plant Anal. 2019, 50, 198-208. [CrossRef]

115. Woodley, A.L.; Drury, C.F.; Yang, X.Y.; Phillips, L.A.; Reynolds, D.W.; Calder, W.; Oloya, T.O. Ammonia volatilization, nitrous oxide emissions, and corn yields as influenced by nitrogen placement and enhanced efficiency fertilizers. Soil Sci. Soc. Am. J. 2020, 84, 1327-1341. [CrossRef]

116. Silva, D.R.G.; Pereira, A.F.; Dourado, R.L.; Silva, F.P.D.; Ávila, F.W.; Faquin, V. Productivity and efficiency of nitrogen fertilization in maize under different levels of urea and NBPT-treated urea. Ciênc. Agrotecnol. 2011, 35, 516-523. [CrossRef]

117. Graham, R.F.; Greer, K.D.; Villamil, M.B.; Nafziger, E.D.; Pittelkow, C.M. Enhanced-Efficiency Fertilizer Impacts on Yield-Scaled Nitrous Oxide Emissions in Maize. Soil Sci. Soc. Am. J. 2018, 82, 1469-1481. [CrossRef]

118. Yang, M.; Fang, Y.; Sun, D.; Shi, Y. Efficiency of two nitrification inhibitors (dicyandiamide and 3, 4-dimethypyrazole phosphate) on soil nitrogen transformations and plant productivity: A meta-analysis. Sci. Rep. 2016, 6, 22075. [CrossRef] [PubMed]

119. Gu, Y.; Mi, W.; Xie, Y.; Ma, Q.; Wu, L.; Hu, Z.; Dai, F. Nitrapyrin affects the abundance of ammonia oxidizers rather than community structure in a yellow clay paddy soil. J. Soils Sediments 2019, 19, 872-882. [CrossRef]

120. Yang, G.; Ji, H.; Sheng, J.; Zhang, Y.; Feng, Y.; Guo, Z.; Chen, L. Combining Azolla and urease inhibitor to reduce ammonia volatilization and increase nitrogen use efficiency and grain yield of rice. Sci. Total Environ. 2020, 743, 140799. [CrossRef]

121. Mi, W.; Zheng, S.; Yang, X.; Wu, L.; Liu, Y.; Chen, J. Comparison of yield and nitrogen use efficiency of different types of nitrogen fertilizers for different rice cropping systems under subtropical monsoon climate in China. Eur. J. Agron. 2017, 90, 78-86. [CrossRef]

122. Yao, H.; Huang, S.; Qiu, Q.; Li, Y.; Wu, L.; Mi, W.; Dai, F. Effects of different fertilizers on the abundance and community structure of ammonia oxidizers in a yellow clay soil. Appl. Microbiol. Biotechnol. 2016, 100, 6815-6826. [CrossRef]

123. He, T.; Liu, D.; Yuan, J.; Ni, K.; Zaman, M.; Luo, J.; Ding, W. A two years study on the combined effects of biochar and inhibitors on ammonia volatilization in an intensively managed rice field. Agric. Ecosyst. Environ. 2018, 264, 44-53. [CrossRef]

124. Azeem, B.; KuShaari, K.; Man, Z.B.; Basit, A.; Thanh, T.H. Review on materials \& methods to produce controlled release coated urea fertilizer. J. Control. Release 2014, 181, 11-21. [CrossRef] [PubMed]

125. Geng, J.; Sun, Y.; Zhang, M.; Li, C.; Yang, Y.; Liu, Z.; Li, S. Long-term effects of controlled release urea application on crop yields and soil fertility under rice-oilseed rape rotation system. Field Crop. Res. 2015, 184, 65-73. [CrossRef]

126. Karydogianni, S.; Darawsheh, M.K.; Kakabouki, I.; Zisi, C.; Folina, A.E.; Roussis, I.; Tselia, Z.; Bilalis, D. Effect of nitrogen fertilizations, with and without inhibitors, on cotton growth and fiber quality. Agron. Res. 2020, 18, 432-449. [CrossRef]

127. Bronson, K.F.; Hunsaker, D.J.; Mon, J.; Andrade-Sanchez, P.; White, J.W.; Conley, M.M.; Barnes, E.M. Improving nitrogen fertilizer use efficiency in surface-and overhead sprinkler-irrigated cotton in the desert Southwest. Soil Sci. Soc. Am. J. 2017, 81, 1401-1412. [CrossRef]

128. Giannoulis, K.D.; Bartzialis, D.; Skoufogianni, E.; Danalatos, N.G. Innovative Nitrogen Fertilizers Effect on Cotton Cultivation. Commun. Soil Sci. Plant Anal. 2020, 51, 869-882. [CrossRef]

129. Ma, Z.; Gao, X.; Tenuta, M.; Kuang, W.; Gui, D.; Zeng, F. Urea fertigation sources affect nitrous oxide emission from a dripfertigated cotton field in northwestern China. Agric. Ecosyst. Environ. 2018, 265, 22-30. [CrossRef]

130. Zareabyaneh, H.; Bayatvarkeshi, M. Effects of slow-release fertilizers on nitrate leaching, its distribution in soil profile, N-use efficiency, and yield in potato crop. Environ. Earth Sci. 2015, 74, 3385-3393. [CrossRef]

131. Gonzaga, L.C.; Carvalho, J.L.N.; de Oliveira, B.G.; Soares, J.R.; Cantarella, H. Crop residue removal and nitrification inhibitor application as strategies to mitigate $\mathrm{N}_{2} \mathrm{O}$ emissions in sugarcane fields. Biomass Bioenergy 2018, 119, 206-216. [CrossRef] 
132. Antille, D.L.; Hoekstra, N.J.; Lalor, S.T. Field-scale evaluation of calcium ammonium nitrate, urea, and urea treated with N-(n-butyl) thiophosphorictriamide applied to grassland in Ireland. Commun. Soil Sci. Plant Anal. 2015, 46, 1345-1361. [CrossRef]

133. Afshar, R.K.; Mohammed, Y.A.; Chen, C. Enhanced efficiency nitrogen fertilizer effect on camelina production under conventional and conservation tillage practices. Ind. Crop. Prod. 2016, 94, 783-789. [CrossRef]

134. Suter, H.C.; Sultana, H.; Davies, R.; Walker, C.; Chen, D. Influence of enhanced efficiency fertilisation techniques on nitrous oxide emissions and productivity response from urea in a temperate Australian ryegrass pasture. Soil Res. 2016, 54, 523-532. [CrossRef]

135. Rowlings, D.W.; Scheer, C.; Liu, S.; Grace, P.R. Annual nitrogen dynamics and urea fertilizer recoveries from a dairy pasture using $15 \mathrm{~N}$; effect of nitrification inhibitor DMPP and reduced application rates. Agric. Ecosyst. Environ. 2016, 216, 216-225. [CrossRef]

136. Lester, D.W.; Bell, M.J.; Bell, K.L.; Migliorati, M.D.A.; Scheer, C.; Rowlings, D.; Grace, P.R. Agronomic responses of grain sorghum to DMPP-treated urea on contrasting soil types in north-eastern Australia. Soil Res. 2016, 54, 565-571. [CrossRef]

137. Sloan, J.J.; Anderson, W.B. Bermudagrass response to surface-applied urea amended with calcium chloride or ammonium thiosulfate. Commun. Soil Sci. Plant Anal. 2001, 32, 1915-1929. [CrossRef]

138. Chao, X.; Liang-Huan, W.; XiaoTang, J.; Fu-Suo, Z. Effects of nitrogen fertilizer with nitrification inhibitor DMPP (3,4dimethylpyrazole phosphate) on nitrate accumulation and quality of cabbage (Brassica campastris L. ssp. pekinesis). Agric. Sci. China 2004, 3, 622-626.

139. Zhao, Z.; Wu, D.; Bol, R.; Shi, Y.; Guo, Y.; Meng, F.; Wu, W. Nitrification inhibitor's effect on mitigating N2O emissions was weakened by urease inhibitor in calcareous soils. Atmos. Environ. 2017, 166, 142-150. [CrossRef]

140. Liu, T.; Liang, Y.; Chu, G. Nitrapyrin addition mitigates nitrous oxide emissions and raises nitrogen use efficiency in plastic-filmmulched drip-fertigated cotton field. PLoS ONE 2017, 12, e0176305. [CrossRef]

141. Wallace, A.J.; Armstrong, R.D.; Harris, R.H.; Belyaeva, O.N.; Grace, P.R.; Partington, D.L.; Scheer, C. Fertiliser timing and use of inhibitors to reduce $\mathrm{N}_{2} \mathrm{O}$ emissions of rainfed wheat in a semi-arid environment. Nutr. Cycl. Agroecosyst. 2018, 112, $231-252$. [CrossRef]

142. Mohd, K.Y.; Radziah, O.; Samsuri, A. Field evaluation of newly-developed controlled release fertilizer on rice production and nitrogen uptake. Sains Malays. 2017, 46, 925-932. [CrossRef]

143. Borges, B.M.M.N.; Peixoto, F.R.; Braga, M.D.M.; Brunozzi, B.D.B.; Silveira, M.L.; Coutinho, E.L.M. Response of bermudagrass to enhanced-efficiency fertilizers, application strategies and release under tropical conditions. Aust. J. Crop. Sci. 2020, 14, 108-115. [CrossRef] 